Research papers

\title{
Computational Fluid Dynamics simulations of the Late Pleistocene Lake Bonneville Flood
}

\author{
José M. Abril-Hernández ${ }^{\mathrm{a}, *}$, Raúl Periáñez ${ }^{\mathrm{a}}$, Jim E. O'Connor ${ }^{\mathrm{b}}$, Daniel Garcia-Castellanos ${ }^{\mathrm{c}}$ \\ a University of Seville, Departamento de Física Aplicada I, ETSIA, Sevilla, Spain \\ ${ }^{\mathrm{b}}$ U.S. Geological Survey, 2130 SW Fifth Ave., Portland, OR, 97201, USA \\ ${ }^{\mathrm{c}}$ Instituto de Ciencias de la Tierra Jaume Almera, ICTJA-CSIC, Solé i Sabarís s/n, 08028 Barcelona, Spain
}

\section{A R T I C L E I N F O}

This manuscript was handled by Corrado Corradini, Editor-in-Chief, with the assistance of Gokmen Tayfur, Associate Editor

Keywords:

Bonneville Flood

Numerical simulation

Fluid Dynamics

Incision model

Erodibility coefficient

\begin{abstract}
A B S T R A C T
At approximately $18.0 \mathrm{ka}$, pluvial Lake Bonneville reached its maximum level. At its northeastern extent it was impounded by alluvium of the Marsh Creek Fan, which breached at some point north of Red Rock Pass (Idaho), leading to one of the largest floods on Earth. About $5320 \mathrm{~km}^{3}$ of water was discharged into the Snake River drainage and ultimately into the Columbia River. We use a OD model and a 2D non-linear depth-averaged hydrodynamic model to aid understanding of outflow dynamics, specifically evaluating controls on the amount of water exiting the Lake Bonneville basin exerted by the Red Rock Pass outlet lithology and geometry as well as those imposed by the internal lake geometry of the Bonneville basin. These models are based on field evidence of prominent lake levels, hypsometry and terrain elevations corrected for post-flood isostatic deformation of the lake basin, as well as reconstructions of the topography at the outlet for both the initial and final stages of the flood. Internal flow dynamics in the northern Lake Bonneville basin during the flood were affected by the narrow passages separating the Cache Valley from the main body of Lake Bonneville. This constriction imposed a waterlevel drop of up to $2.7 \mathrm{~m}$ at the time of peak-flow conditions and likely reduced the peak discharge at the lake outlet by about $6 \%$. The modeled peak outlet flow is $0.85 \cdot 10^{6} \mathrm{~m}^{3} \mathrm{~s}-1$. Energy balance calculations give an estimate for the erodibility coefficient for the alluvial Marsh Creek divide of $\sim 0.005 \mathrm{~m} \mathrm{y}^{-1} \mathrm{~Pa}^{-1.5}$, at least two orders of magnitude greater than for the underlying bedrock at the outlet. Computing quasi steady-state water flows, water elevations, water currents and shear stresses as a function of the water-level drop in the lake and for the sequential stages of erosion in the outlet gives estimates of the incision rates and an estimate of the outflow hydrograph during the Bonneville Flood: About 18 days would have been required for the outflow to grow from $10 \%$ to $100 \%$ of its peak value. At the time of peak flow, about $10 \%$ of the lake volume would have already exited; eroding about $1 \mathrm{~km}^{3}$ of alluvium from the outlet, and the lake level would have dropped by about $10.6 \mathrm{~m}$.
\end{abstract}

\section{Introduction}

Lake Bonneville (Fig. 1) was the largest pluvial lake of the western United States during the Late Pleistocene (see Oviatt and Shroder, 2016, and references within). A key event in its history was the giant flood at $18.0 \mathrm{ka}$ (ka: thousands of calendar years before present) which discharged about $5320 \mathrm{~km}^{3}$ of water with a peak flow of $\sim 1 \mathrm{~Sv}$ (Sverdrup; $\left.1 \mathrm{~Sv}=10^{6} \mathrm{~m}^{3} \mathrm{~s}^{-1}\right)$. The flood, one of the largest ever recorded on Earth (O'Connor et al., 2013), followed the courses of the rivers Snake and Columbia before reaching the Pacific Ocean. It was first documented by G.K. Gilbert in the 1870s during his inspection of the outlet at Red Rock Pass (Gilbert, 1875, 1890), and readdressed only in the 1950s by Harold Malde and co-workers (Malde, 1960). O'Connor (2016) provides a recent review of the flood and its discovery.
Since ca 30 ka Lake Bonneville grew within its closed basin, rising, with oscillations, until about $18 \mathrm{ka}$, when it reached its maximum possible stage associated with the lowest elevation on the basin rim at the crest of an alluvial fan athwart the head of Marsh Creek Valley, just north of Red Rock Pass, Idaho. Stabilized by either surface overflow or groundwater flow through the Marsh Creed fan and into the Snake River drainage, the lake stabilized briefly at its maximum Bonneville level and formed the prominent Bonneville shoreline (Oviatt and Jewell, 2016). Soon after, the out-flowing water began eroding the alluvial barrier, thereby increasing outflow channel dimensions and discharge, initiating a positive feedback process by which initial overflow grew exponentially to a catastrophic flood (Gilbert, 1890; GarciaCastellanos et al., 2009). When the incising channel reached the underlying bedrock or more resistant materials beneath the Marsh Creek

\footnotetext{
* Corresponding author at: Dpto. Física Aplicada I, ETSIA, Universidad de Sevilla, Carretera de Utrera km 1, D.P. 41013, Sevilla Spain.

E-mail address: jmabril@us.es (J.M. Abril-Hernández).
} 

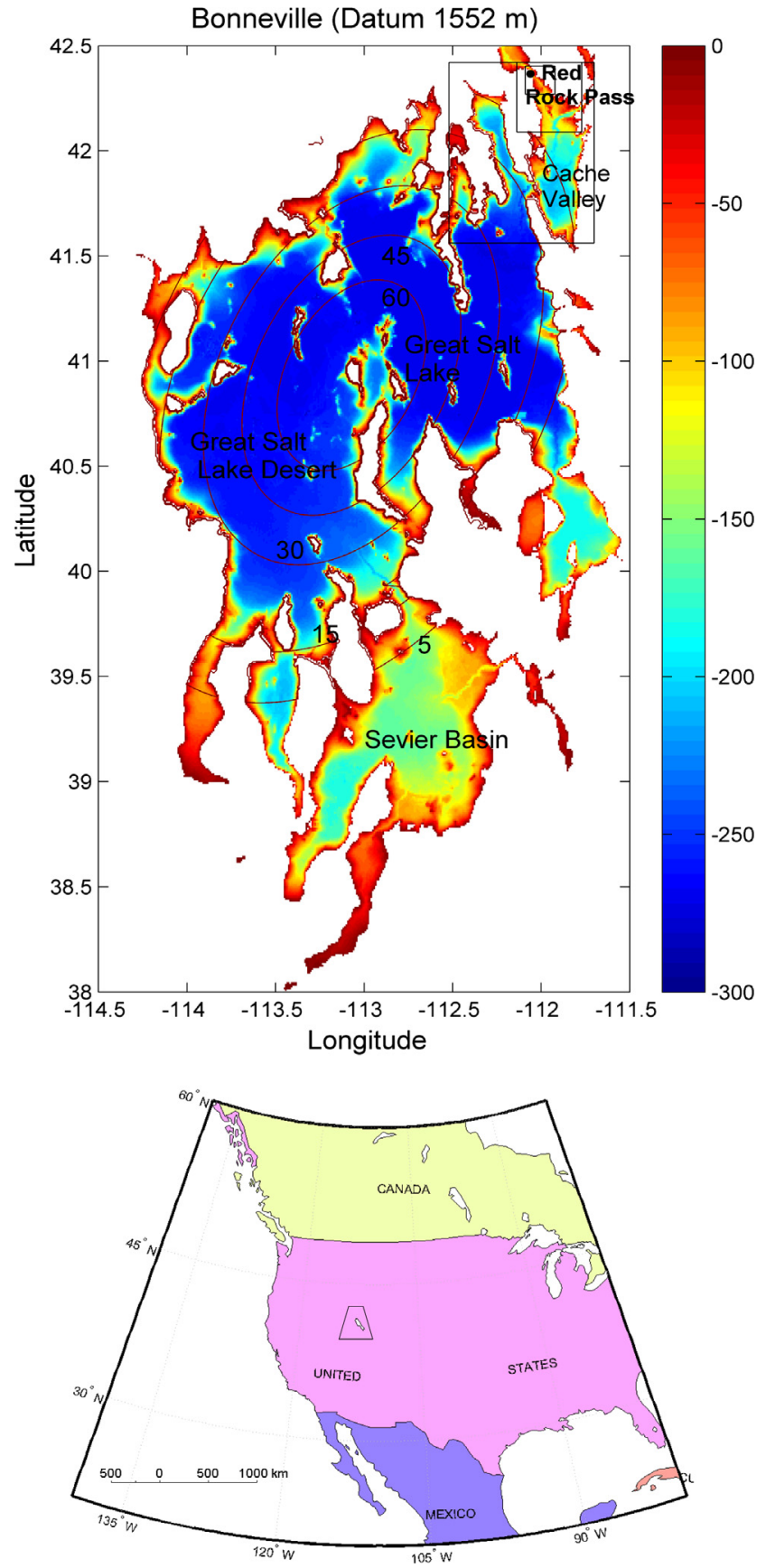

Fig. 1. Modern terrain elevations referred to a datum of $1552 \mathrm{~m}$ a.s.l. with a 30 arc-second resolution (from GEBCO_08 database). The elliptical contour lines are defining the isostatic deformation (for 60, 45, 30, 15 and $5 \mathrm{~m}$, from the central area towards the shoreline), according to Crittenden (1963). Nested rectangles show the computational domains used for spatial resolutions of 4, 2 and 1 arc-seconds, respectively.

fan, the incision rate sharply decreased, forming a new stable elevation known as the Provo level. From the extensive radiocarbon chronology, Oviatt (2015) concluded "a reasonable flood age ... is $18 \mathrm{ka}$ with an uncertainty of several hundred years". After stabilizing at this level for about three thousand years, the lake returned to a closed-basin hydrology (endorheism) as climate went drier, and by about $13 \mathrm{ka}$ BP it had dropped to elevations similar to those historically recorded for the Great Salt Lake (Oviatt and Jewell, 2016).

The total lake-level drop and volume released during the Bonneville Flood is given by the difference between the Bonneville and Provo paleoshorelines. Nevertheless, this is not a straightforward measurement because of locally ambiguous field evidence (Atwood et al., 2016) and deformation by non-uniform isostatic rebound following the Provo stage of the Lake Bonneville (Crittenden, 1963). Additionally, the Provo shoreline in many places consists of double beaches and double wave-cut notches which are vertically separated by as much as $3 \mathrm{~m}$. From multiple Bonneville and Provo shoreline observations, Miller et al. (2013) estimate the total lake-level drop during the Bonneville Flood being $\sim 125 \mathrm{~m}$. We use this value for our analysis, although it may be subject to further refinements. It is slightly greater than the 115 m estimated by Gilbert in 1890 (see O'Connor, 2016). And Jewell (2016) noted that the depositional Bonneville elevations reported by Miller et al. (2013) were higher than the erosional shorelines identified in his study, in places by as much as $15 \mathrm{~m}$. Jewell (2016) retained the Bonneville shoreline altitude of $1552 \mathrm{~m}$ and normalized all other measurements to an arbitrary but uniform Bonneville-Provo vertical separation of $107 \mathrm{~m}$.

The peak flow attained during the Bonneville Flood has been estimated in different manners from several types of downstream erosional features and flood deposits (reviewed by O'Connor, 2016). Jarrett and Malde (1987) studied a constricted reach of the Snake River Canyon at the mouth of Sinker Creek and several places about $53 \mathrm{~km}$ upstream. By using the step-backwater method they estimated a peak discharge of 0.935 Sv. Also, from step-backwater calculations, O'Connor (1993, pp. 14-16) calculated peak discharge for nine separate reaches between Red Rock Pass and Lewiston. These ranged from 0.85 to $1.0 \mathrm{~Sv}$ near the outlet at Red Rock Pass to about 0.6 Sv 1100 km downstream near Lewiston. Additionally, O'Connor (1993) calculated a maximum plausible discharge of $1.1 \mathrm{~Sv}$ assuming critical flow at Red Rock Pass for conditions of modern topography and a maximum Bonneville level of $1552 \mathrm{~m}$ a.s.l., $95 \mathrm{~m}$ above the present outlet bottom.

Total outflow during the Bonneville Flood can be estimated from the total water level drop and the lake hypsometry. Jarrett and Malde (1987) estimated a total discharge of $4700 \mathrm{~km}^{3}$. Additionally, from rudimentary dam-break modeling fit to downstream estimates of peak flow, O'Connor (1993, pp. 36-40) estimated that flow exceeded 0.5 Sv for about 18 days at Red Rock Pass.

Despite numerous quantitative studies devoted to the Bonneville Flood, questions remain, particularly regarding flood hydrodynamics and the control exerted by the erosion of the outlet during the event. Key issues include: i) determination of plausible hydrographs for the flood, including timing of peak flow and duration, and assessment of water levels, water currents, bottom shear stresses and incision rates; ii) a quantitative assessment of the energy balance at the outlet, which likely relates to the total eroded volume, outlet erodibility, and the energy dissipated by the water flow; iii) the role of the internal hydrodynamics of the lake and lake geometry effects on flow exiting the outlet; specifically the likely hydraulic control exerted by the narrow passage of the Bear River canyon where it connects the Bear River Valley and Great Salt Lake with the Cache Valley; iv) the factors controlling the end of the flood; and v) the progression and timing of the erosion of the outlet that best explains the inferred peak discharge and flood volume.

We address these questions by applying $0 \mathrm{D}$ and 2D hydrodynamic models to the lake and outflow. These are applied in conjunction with current understanding of the Lake Bonneville history and downstream flow conditions from previous studies as well as current theory of incision processes in river channels. The models are supported by available DEM data and recent increases computational capability.

\section{Flow modeling; data, methods and application}

Vertically-averaged, two-dimensional (2D) hydrodynamic models have been widely applied to model outburst floods (e.g., Miyamoto et al., 2006; Carrivik, 2007; Bohorquez and Darby, 2008; Denlinger and O'Connell, 2009; Alho et al., 2010; Huang et al., 2014; Bohorquez et al., 2016). Most applications have focused on the flood route and have 
relied on specified input discharges or hydrographs as a boundary condition. Some have assumed instantaneous dam-breaks at the basin outlet (Denlinger and O'Connell, 2009; Bohorquez et al., 2016). Some recent applications have also coupled the hydraulics and the sediment transport under imposed flow hydrographs (Carrivik, 2007; Huang et al., 2014).

The major limitations of these modeling approaches have been summarized by Miyamoto et al. (2006): i) the pre-flood paleotopography must be reliably estimated and reconstructed; ii) the model must account for major topographic changes during the flood; iii) the Manning's coefficient (or other energy-loss parameters) for megafloods are not well known yet must be estimated. The present approach for the Bonneville Flood takes advantage of the relatively simple setting at the outlet, enabling reasonable accounting of these uncertainties. Moreover, the modeling addresses conditions at specific part of the flood route that exerts the greatest control on the ultimate downstream flooding-the lake outlet.

The modeling strategy entailed 4 steps:

i) Creating a digital elevation model representing the former configuration of the lake at the initial stage of the flood, its hypsometry, and the initial and final topography of the outlet, taking into account the post-flood isostatic rebound of the lake basin.

ii) Development of a basic 0D model of the outlet, which defines interrelations among water-level drop, water flow and outlet erosion. This 0D-model also provides an efficient means of hypothesis testing.

iii) Adaptation of a 2D hydrodynamic model capable of modeling flow within the lake basin as well as through the developing outlet in a manner suitable for addressing the key questions outlined above.

iv) Designing modeling strategies to divide the problem into tractable components, involving different spatial scales and resolutions leading to the quasi steady-state solutions for sequential stages of the flood.

\subsection{Terrain data, isostatic corrections, and Lake Bonneville hypsometry}

Regional terrain elevation data have been obtained from GEBCO08 database (www.gebco.net), with a 30 arc-second resolution (Fig. 1), and from the USGS (https://www.usgs.gov/), with 1 arc-second DEM. The 1 arc-second data, provided in sheets of $1.0^{\circ} \times 1.0^{\circ}$, has been processed to generate numerical meshes with resolutions of 1,2 and 4 arc-seconds by using QGIS 2.18.0 software (https://www.qgis.org/es/ site/). These data have been merged to generate the various numerical domains used in this study.

Modern terrain elevations have isostatically risen since the Bonneville Flood owing to the removal of the mass of the lake, both by the flood itself and by the subsequent desiccation of the Bonneville basin. Crittenden (1963) documented a maximum isostatic rebound of $61 \mathrm{~m}$ in the center of the former Bonneville Lake $\left(113.0682^{\circ} \mathrm{W}\right.$, $40.9333^{\circ} \mathrm{N}$ ) and that rebound decreased towards the shorelines, defining roughly elliptical contour lines of equal uplift. We used the central point, the eccentricity of the elliptical contours, and the geodetic azimuth defined by the major axis to derive a second order polynomial fit to the isostatic uplift. We used this fit to subtract postBonneville level uplift from the modern terrain elevations. Corrections were applied to terrain-grid points with elevations below the $1560 \mathrm{~m}$, thereby including the entire domain of the lake at its maximum $1552 \mathrm{~m}$ normalization level as specified by Jewell (2016). A comparison between the $1552 \mathrm{~m}$ elevation-contour in the modern topography and where the $1552 \mathrm{~m}$ contour would lie with the load of the lake was evaluated in a similar analysis by Adams and Bills (2016), which shows that this type of adjustment closely accounts for shoreline features throughout the lake basin.

We compute the free surface of the former rebound-corrected lake at 1-m intervals for the 125-m drop between the 1552-m Bonneville level to the Provo level (adopted as $1427 \mathrm{~m}$ per Miller et al., (2013)). This enables determination of the free surface of the lake as a function of the water-level drop during the course of outflow.

\subsection{Terrain reconstruction near the outlet for the Bonneville and Provo levels}

A key area of terrain reconstruction is at the outlet near Red Rock Pass and the Marsh Creek fan. First, all terrains elevations were reduced by the isostatic deformation correction as described in Subsection 2.1. At Red Rock Pass, where loading was small, this adjustment was $\sim 0 \mathrm{~m}$, but affects elevations at a rate of $\sim 0.5 \mathrm{~m} / \mathrm{km}$ to south-southwest in the direction of maximum deformation (Fig. 1). This adjustment to the terrain gives a first approximation to conditions at the end of the Bonneville Flood when the lake stabilized at the Provo level. But the outlet has been partly filled with landslide debris and post-flood alluvium (Gilbert, 1890; Janecke and Oaks, 2011) such that the present topography, even after isostatic correction, is about $35 \mathrm{~m}$ higher than the Provo level of $1427 \mathrm{~m}$.

To adjust the post-flood outlet topography to be consistent with the known Provo level, we identified those grid-cells in the northern Cache Valley north to Marsh Valley, north of Red Rock Pass (Figs. 1 and 2), having elevations between $1427 \mathrm{~m}$ (the Provo level) and $1427+\Delta z \mathrm{~m}$, with $\Delta z$ ranging from 25 to $37 \mathrm{~m}$ from south to north. These grid-cells define the main course of the channel incised by the Bonneville Flood. The elevations of these cells were adjusted to define a $1427 \mathrm{~m}$ divide south of Swan Lake with a 0.003 slope to the north (Fig. 2). This creates an outlet topography consistent with the Provo level at the end of the Bonneville Flood as well as the local fill and geomorphology conditions (Gilbert, 1890; Janecke and Oaks, 2011).

Similarly, reconstructing the former conditions of the outlet at the Bonneville level, prior to incision of Marsh Creek fan, entailed applying the isostatic correction to the modern terrain elevations. Then, the nowentrenched Marsh Creek fan surface was extrapolated westward to fill the valley bottom. This was based on defining a radiation point $\mathrm{A}$ $\left(112.0331^{\circ} \mathrm{W}, 42.4003^{\circ} \mathrm{N}\right)$ at the present fan apex (Fig. 2) from which the mean slope of the fan was determined for several azimuths and fitted to a polynomial function. The azimuth with the lowest slope served to define the point $\mathrm{A}^{\prime}$, at the western edge of the outlet trench $\left(112.0632^{\circ} \mathrm{W}, 42.3685^{\circ} \mathrm{N}\right)$. This location was inferred to represent the initial spill-over point and its elevation was reset to the maximum Bonneville level of $1552 \mathrm{~m}$ a.s.l. For each grid-point $\mathrm{P}$ within the outlet area below $1552 \mathrm{~m}$, the distance to point A can be computed, as well as the azimuth of the segment PA. A value for the slope along such azimuth is assigned according to the above polynomial fit. The resulting extrapolation of the Marsh Creek fan was then numerically smoothed, thereby providing a reconstruction of the Marsh Creek fan surface consistent with the maximum Bonneville level.

These two topographic reconstructions of the outlet conditions define plausible starting and ending states of the flood consistent with the shoreline elevations. By differencing the two models, we estimate that $1.13 \mathrm{~km}^{3}$ was eroded from the outlet during the course of the flood.

\subsection{OD model}

The $0 \mathrm{D}$ model is based on a simple rectangular weir scenario at the outlet (Fig. 3; table 1 summarizes the symbols used in this work and the sensitivity tests reported throughout the Results section). For this standard engineering configuration (e.g. Henderson, 1966, p. 174-178, chap. 5), the water flow, $Q$, can be expressed as a function of the hydraulic head over the sill (as represented by the weir crest), $h_{S}$ :

$Q=\alpha W h_{S}^{3 / 2}$

where $h_{S}=z_{s}-z_{0}$ is the difference between the water level of the lake, $z_{0}$, and the depth of the sill, $z_{s}$, both measured positive downwards from 

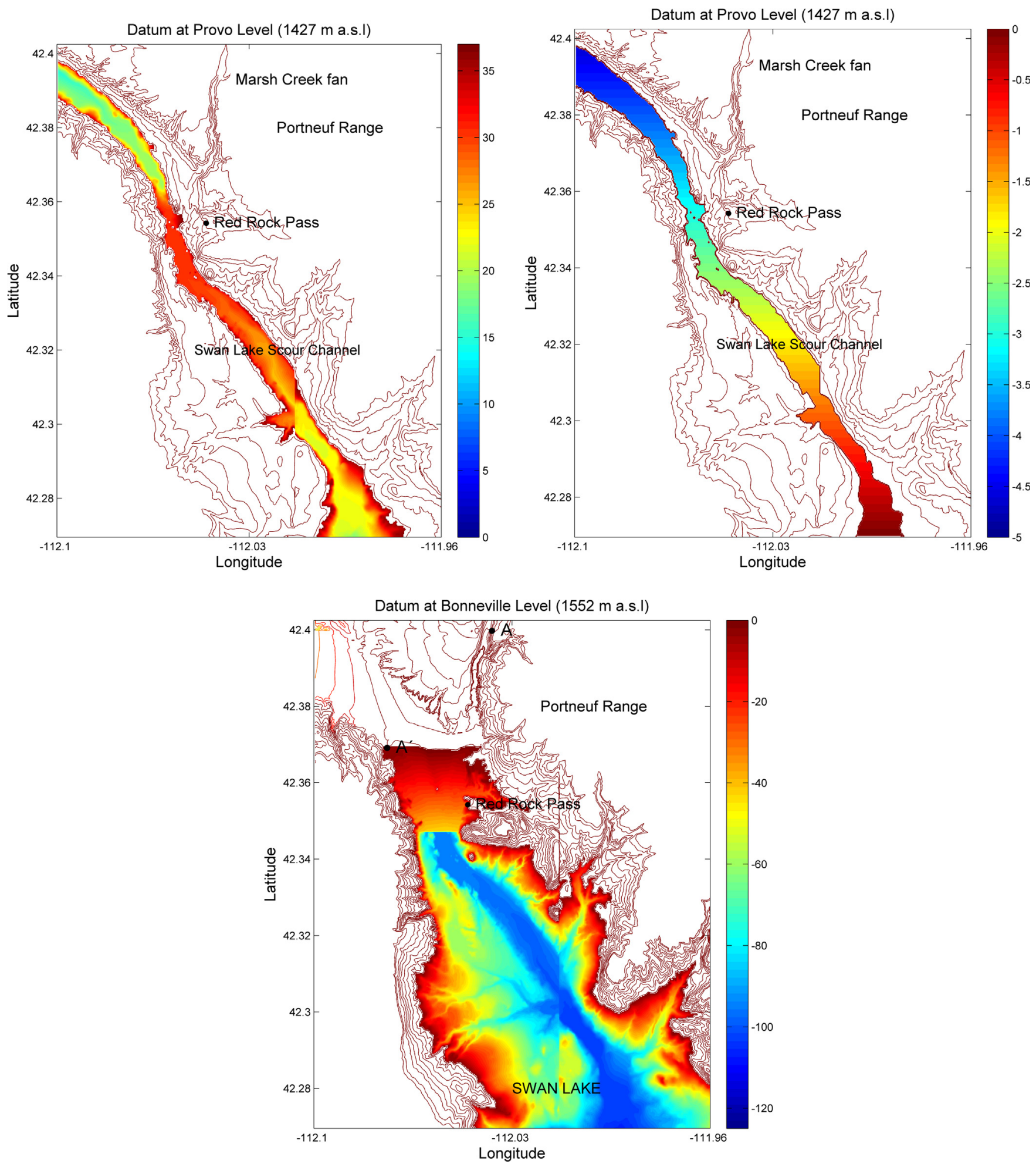

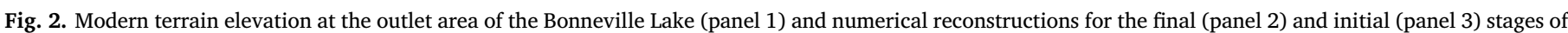

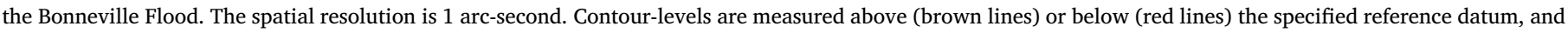

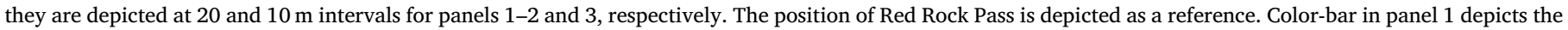

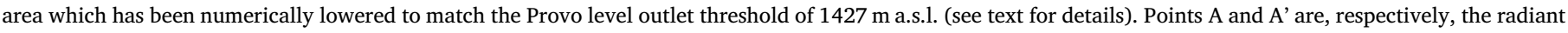

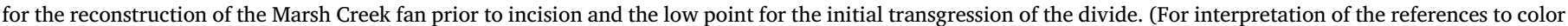
in this figure legend, the reader is referred to the web version of this article.)

the $1552 \mathrm{~m}$ a.s.l. datum of the Bonneville level, $W$ is the cross-section width, and $\alpha$ is a coefficient which includes, among other corrections, the effect of the contraction of the flow at the weir ( $\alpha \approx 1.1$ in S.I. units). The depth of the water at the sill is $d=2 / 3 h_{S}$ for conditions of critical flow, a simplifying assumption adopted in this 0D model. The cross-sectional averaged water velocity at the sill, $v_{S}$, can be estimated as $v_{S}=Q /(W d)$. The bottom shear stress, $\tau_{\mathrm{b}}$, can be estimated by the quadratic law: 


\section{Bonneville Level (1552 m a.s.I.)}

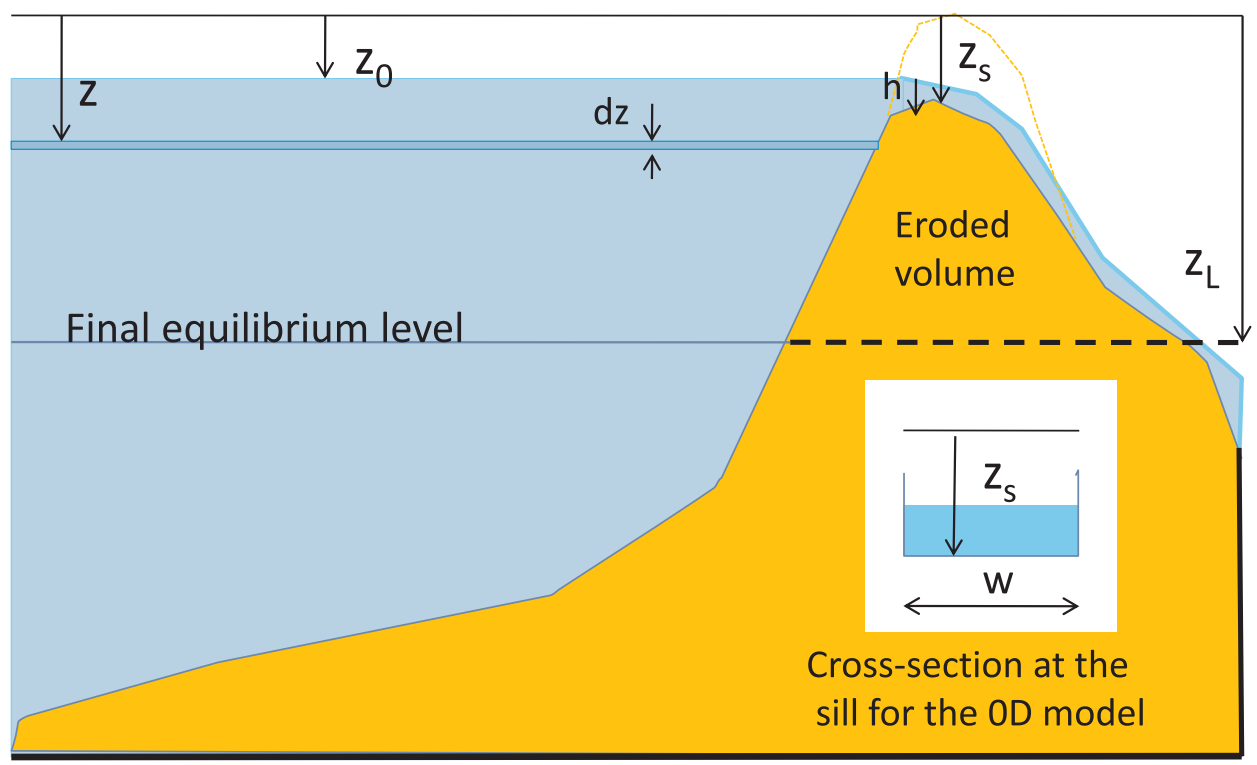

Fig. 3. Definition sketch for the 0-D hydraulic model. The water level in the lake, $z_{0}$, and the depth of the sill, $z_{s}$, are measured positive downwards from the datum placed at the Bonneville level (1552 $\mathrm{m}$ a.s.1.). The final equilibrium level $z_{L}$ is the Provo level (1427 ma.s.1.), $h_{S}=z_{s}-z_{0}$ is the hydraulic head over the sill, $A\left(z_{0}\right)$ is the free surface of the lake at water level $z_{0}$, and $A\left(z_{0}\right) d z$ is the elemental water volume used for the energy balance.

Table 1

List of symbols for physical magnitudes used in 0-D and 2-D models (physical dimensions are $\mathrm{L}=$ length, $\mathrm{M}=$ mass, $\mathrm{T}=$ time) and sensitivity tests conducted in this work. The reported parameter values (sensitivity tests) are in the International System of Units.

\begin{tabular}{|c|c|c|}
\hline $\mathrm{Q}$ & $\mathrm{L}^{3} \mathrm{~T}^{-1}$ & Water flow (Eq. (1)) \\
\hline $\mathrm{z}_{0}$ & $\mathrm{~L}$ & Water level in the lake, measured positive downwards from the datum placed at the Bonneville level (Fig. 3) \\
\hline $\mathrm{z}_{\mathrm{s}}$ & $\mathrm{L}$ & Depth of the sill, measured positive downwards from the datum placed at the Bonneville level (Fig. 3) \\
\hline $\mathrm{h}_{\mathrm{S}}=\mathrm{z}_{\mathrm{s}}-\mathrm{z}_{0}$ & $\mathrm{~L}$ & Hydraulic head over the sill (Fig. 3, Eq. (1)) \\
\hline $\mathrm{A}\left(\mathrm{z}_{0}\right)$ & $\mathrm{L}^{2}$ & Free surface of the lake at water level $\mathrm{z}_{0}$ (Fig. 3) \\
\hline $\mathrm{A}\left(\mathrm{z}_{0}\right) \mathrm{dz}$ & $\mathrm{L}^{3}$ & Elemental water volume used for the energy balance (Fig. 3) \\
\hline W & $\mathrm{L}$ & Width of the rectangular cross-section of the sill (Eq. (1)) \\
\hline $\mathrm{d}=2 / 3 \mathrm{~h}_{\mathrm{S}}$ & $\mathrm{L}$ & Water depth at the sill for critical flow conditions \\
\hline $\mathrm{v}_{\mathrm{S}}$ & $\mathrm{LT}^{-1}$ & Cross-sectional averaged water velocity at the sill \\
\hline$\alpha$ & $\mathrm{L}^{1 / 2} \mathrm{~T}^{-1}$ & Scaling and correction factor (for the contraction of the flow at the weir, Eq. (1)) \\
\hline$\tau_{\mathrm{b}}$ & $\mathrm{ML}^{-1} \mathrm{~T}^{-2}$ & Bottom shear stress at the sill (Eq. (2)) \\
\hline$\rho$ & $\mathrm{ML}^{-3}$ & The density of water \\
\hline $\mathrm{k}_{\mathrm{f}}$ & $\mathrm{M}^{0} \mathrm{~L}^{0} \mathrm{~T}^{0}$ & Bed friction coefficient (Eq. (2)) \\
\hline $\mathrm{n}$ & $\mathrm{L}^{-1 / 3} \mathrm{~T}$ & Manning's coefficient \\
\hline $\mathrm{g}$ & $\mathrm{LT}^{-2}$ & Acceleration of gravity \\
\hline $\mathrm{k}_{\mathrm{b}}$ & $\mathrm{M}^{-3 / 2} \mathrm{~L}^{5 / 2} \mathrm{~T}^{2}$ & Erodibility coefficient (Eq. (3)) \\
\hline $\mathrm{f}_{\mathrm{y}}$ & $\mathrm{M}^{0} \mathrm{~L}^{0} \mathrm{~T}^{0}$ & Fraction of the dissipated energy contributing to bed erosion (Eq. (3)) \\
\hline$\varepsilon_{\mathrm{V}}$ & $\mathrm{ML}^{-1} \mathrm{~T}^{-2}$ & Average energy per unit volume required for erosion (Eq. (3)) \\
\hline$f_{L}$ & $\mathrm{M}^{0} \mathrm{~L}^{0} \mathrm{~T}^{0}$ & Scaling factor relating lateral erosion with the incision rate (Eq. (4)) \\
\hline $\mathrm{z}_{\mathrm{B}}$ & $\mathrm{L}$ & Depth of the bedrock level at the sill \\
\hline $\mathrm{z}_{\mathrm{L}}$ & $\mathrm{L}$ & Depth of the sill at the end of the flood (the Provo level) \\
\hline $\mathrm{u}, \mathrm{v}$ & $\mathrm{LT}^{-1}$ & Depth averaged water velocities along the $\mathrm{x}$ (WE) and y (NS) axis, respectively (Eqs. (6)-(8)) \\
\hline $\mathrm{h}$ & $\mathrm{L}$ & The depth of water below the mean level (Eqs. (6)-(8)) \\
\hline$\zeta$ & $\mathrm{L}$ & Displacement of the water surface above the mean level, measured upwards (Eqs. (6)-(8)) \\
\hline $\mathrm{H}=\mathrm{h}+\zeta$ & $\mathrm{L}$ & The total water depth (Eqs. (6)-(8)) \\
\hline $\mathrm{w}$ & $\mathrm{L}^{0} \mathrm{~T}^{-1}$ & The Earth's rotational angular velocity \\
\hline$\lambda$ & $\mathrm{L}^{0}$ & The geographical latitude \\
\hline$\Omega=2 \mathrm{w} \sin \lambda$ & $\mathrm{L}^{0} \mathrm{~T}^{-1}$ & The Coriolis parameter (Eqs. (6)-(8)) \\
\hline A & $\mathrm{L}^{2} \mathrm{~T}^{-1}$ & Horizontal eddy viscosity (Eqs. (6)-(8)) \\
\hline$\tau_{\mathrm{u}}, \tau_{\mathrm{v}}$ & $\mathrm{ML}^{-1} \mathrm{~T}^{-2}$ & Friction stresses along the $\mathrm{x}$ and $\mathrm{y}$ axis, respectively (Eqs. (6)-(8)) \\
\hline $\mathrm{V}_{\text {out }}$ & & Cumulated outflow (Eq. (11)) \\
\hline $\mathrm{E}_{\mathrm{p}}$ & $\mathrm{ML}^{2} \mathrm{~T}^{-2}$ & Gravitational potential energy \\
\hline $\mathrm{V}_{\text {ERD }}$ & $\mathrm{L}^{3}$ & Eroded volume at the outlet \\
\hline $\mathrm{W}_{\mathrm{r}}$ & $\mathrm{ML}^{2} \mathrm{~T}^{-2}$ & Dissipated energy by the water flow in the outlet area \\
\hline $\mathrm{z}_{\mathrm{SW}}$ & $\mathrm{L}$ & Water level south of Swan Lake, in Cache Valley, measured positive downwards from the datum placed at the Bonneville level (Fig. 3) \\
\hline \multicolumn{3}{|c|}{ Sensitivity tests } \\
\hline Parameter & Model & Nominal and test values \\
\hline$\left(\mathrm{z}_{\mathrm{s}}, \mathrm{W}\right)$ & OD & Initial configuration of the rectangular sill $(3,30)$ vs $(5,100)$ (Fig. 4$)$ \\
\hline $\mathrm{f}_{\mathrm{y}} / \varepsilon_{\mathrm{V}}$ & OD & $1.4 \cdot 10^{-9}$ vs $0.7 \cdot 10^{-9}$ and $2.8 \cdot 10^{-9}$ [Fig. ESM- 1$]$ \\
\hline$\Delta x, \Delta y$ & $2 \mathrm{D}$ & Spatial resolution, 1 arc-seconds vs 2 arc-seconds (Fig. 7) \\
\hline $\mathrm{n}$ & $2 \mathrm{D}$ & Manning's coefficient; 0.05 vs 0.04 and 0.06 (Fig. 7 and Fig. ESM-4) \\
\hline A & $2 \mathrm{D}$ & Eddy viscosity; 10 vs 1 and 100 (Fig. ESM-2) \\
\hline
\end{tabular}

In brackets the Equations and figures where the magnitudes first appear, or where the results from the sensitivity tests are reported. 
$\tau_{b}=k_{f} \rho v_{S}^{2}$

where $\rho$ is the density of water, and $k_{f}$ is the bed-friction coefficient which can be written in terms of the Manning's coefficient, $n$, as $k_{f}=g n^{2} / d^{1 / 3}$, with $g$ being the acceleration of gravity (Mayo et al., 2014).

The flow will vary as the lake level drops and as the outlet erodes laterally and vertically during the course of the flood. For estimating the incision rate we used the approach by Abril and Periáñez (2016), based upon the energy balance:

$\frac{d z_{s}}{d t}=k_{b} \tau_{b}^{3 / 2} \quad, \quad k_{b}=\frac{f_{y}}{\varepsilon_{v} \sqrt{\rho k_{f}}} ;$

where $f_{y}$ is the yield factor (the fraction of the stream power contributing to bed erosion), and $\varepsilon_{v}$ is the average energy per unit volume required for erosion through all the involved processes. The ratio $f_{y} / \varepsilon_{v}$ can be estimated from an energy balance applied to two points of an streamline for conditions of known total energy loss (kinetic and potential) and the intervening eroded volume (Abril and Periáñez, 2016). Lateral erosion, thereby widening the cross section, is approximated following the approach by Finnegan and Dietrich (2011) by applying a scaling factor $f_{L}$ :

$\frac{d W}{d t}=f_{L} k_{b} \tau_{b}^{3 / 2}$

Finally, the rate of change in the water level of the lake can be estimated from the water flow and the hypsometric curve, $A\left(z_{0}\right)$ :

$\frac{d z_{0}}{d t}=\frac{Q}{A\left(z_{0}\right)}$

The value of the ratio $f_{y} / \varepsilon_{v}$ in Eq. (3) diminishes markedly when the incision depth $z_{s}$ reaches the bedrock level, $z_{B}\left(z_{B} \approx z_{L}\right.$, see Fig. 3 ). Thus, given initial values for $z_{s}, z_{0}$ and $W$, the system of Eqs. (1)-(5) can be numerically solved to produce time series for all aspects of the flow.

\subsection{D-Hydrodynamic model}

The modeling approach is a pseudo-steady-state analysis, calculating incremental steady-state solutions for different stages of the erosion of the outlet area and lake emptying. This approach reflects our objective to understand broadscale controls on progressive erosion and water outflow during the several days and weeks as the breach enlarged, the lake emptied, and peak discharge first increased and then decreased. It does not capture the more complicated and highly unsteady dam-break conditions of initial breaching and associated wave front dynamics from an instantaneous dam failure, but rather the more gradual processes of progressive erosion and water outflow.

The model applied here is adapted from a robust computational tool devoted to tsunami propagation (Abril et al., 2013; Periáñez and Abril, 2013, 2014a,b). It has been previously applied to the Zanclean flood of the Mediterranean (Periáñez and Abril, 2015; Abril and Periáñez, 2016). It is based on the $2 \mathrm{D}$ depth-averaged barotropic hydrodynamic equations, which describe the propagation of surface shallow water gravity waves (e.g. Kowalik and Murty, 1993):

$\frac{\partial \zeta}{\partial t}+\frac{\partial}{\partial x}(H u)+\frac{\partial}{\partial y}(H v)=0$

$\frac{\partial u}{\partial t}+u \frac{\partial u}{\partial x}+v \frac{\partial u}{\partial y}+g \frac{\partial \zeta}{\partial x}-\Omega v+\frac{\tau_{u}}{\rho H}=A\left(\frac{\partial^{2} u}{\partial x^{2}}+\frac{\partial^{2} u}{\partial y^{2}}\right)$

$\frac{\partial v}{\partial t}+u \frac{\partial v}{\partial x}+v \frac{\partial v}{\partial y}+g \frac{\partial \zeta}{\partial y}+\Omega u+\frac{\tau_{v}}{\rho H}=A\left(\frac{\partial^{2} v}{\partial x^{2}}+\frac{\partial^{2} v}{\partial y^{2}}\right)$

where $u$ and $v$ are the depth averaged water velocities along the $x$ and $y$ axis, $h$ is the depth of water below the mean level, $\zeta$ is the displacement of the water surface above the mean level measured upwards, $H=h$ $+\zeta$ is the total water depth, $\Omega$ is the Coriolis parameter $(\Omega=2 w \sin \lambda$, where $w$ is the Earth's rotational angular velocity and $\lambda$ is latitude), $g$ is acceleration due to gravity, $\rho$ is a mean value of water density and $A$ is the horizontal eddy viscosity. $\tau_{u}$ and $\tau_{v}$ are friction stresses which have been written in terms of a quadratic law:

$\tau_{u}=k_{f} \rho u \sqrt{u^{2}+v^{2}} \quad, \quad \tau_{v}=k_{f} \rho v \sqrt{u^{2}+v^{2}}$

where $k_{f}$ is the bed friction coefficient, specified in terms of the Manning's coefficient and the water depth (see Subsection 2.3). Essentially, these equations express mass and momentum conservation. They have been written in Cartesian coordinates given the relatively small model domain.

The coefficient $A$ in Eqs. (7) and (8) is termed the Eddy Viscosity, and is related to turbulent flow properties and grid size, and may vary by orders of magnitude. Turbulence is still an open problem and can only be parameterized (e.g. the Smagorisnky's scheme, see Cushman-Roisin and Beckers, 2011). Some authors neglect this term (e.g., Bohorquez et al., 2013), but a common approach is to use constant term. This apparently works for many models, including those characterizing extreme events such as tsunami floods and storm surges (e.g., Flather and Hubbert, 1990; Periáñez and Abril, 2013; Abril and Periáñez, 2016). Thus, we have employed a constant value for $A$ of $10 \mathrm{~m}^{2} \mathrm{~s}^{-1}$ as a compromise between excess smoothing of results and numerical stability. The sensitivity of the results to this choice is discussed in Subsection 3.4.

A gravity-wave radiation condition (Herzfeld et al., 2011) was used to calculate the free surface elevation along the northernmost open boundary. A wet/dry algorithm updated continuously the computational domain because of wetting and drying associated with waxing flood inundating previously dry grid-cells and the lowering lake 'drying' computational cells. For this, we adopted the numerical scheme of Kampf (2009). All the equations are solved using explicit finite difference schemes (Kowalik and Murty, 1993) with second order accuracy. In particular, the MSOU (Monotonic Second Order Upstream) is used for the advective non-linear terms in the momentum equations.

The model was applied at three different spatial resolutions, 30 arcseconds $(\sim 750 \mathrm{~m}), 4$ arc-seconds $(\sim 100 \mathrm{~m})$, and 1 arc-second $(\sim 25 \mathrm{~m})$, depending on the model domain and the specific question. For all applications we applied a Manning's coefficient $n=0.03$ for flow within the area of Lake Bonneville, following Bunya et al. (2010). In the incised outlet area, however, a Manning's $n=0.05$ was applied as a base model, referred hereafter at the reference frictional setup. This assignment is similar to other applications of 2D-hydrodynamic models for outburst floods: $n=0.05$ (lake Kuray-Chuja; Bohorquez et al., 2016), $n=0.04-0.05$ (for valley floor and step margins, Missoula floods; Miyamoto et al., 2006), $n=0.1$ (Missoula floods; Alho et al., 2010) or $n=0.03-0.08$ (Altai Mountains; Huang et al., 2014). We do, however, test the sensitivity of the results here to the selection of Manning's $n$.

\section{Results and discussion}

\subsection{Hypsometry}

The hypsometry of the lake controls the volume of outflow. The free surface of the lake, $A\left(z_{0}\right)$, given in $\mathrm{km}^{2}$, has been computed at $1 \mathrm{~m}$ elevation intervals from the terrain model within the range $0 \leq z_{0} \leq 125$, with $z_{0}$ defined as the water-level drop below the Bonneville level, in $\mathrm{m}$. These results define a function of $z_{0}$ fit as third order polynomial $\left(\mathrm{R}^{2}=0.9997\right)$ :

$A\left(z_{0}\right)=4.8240 \cdot 10^{-5} z_{0}^{3}-8.5078 \cdot 10^{-2} z_{0}^{2}-1.0834 \cdot 10^{2} z_{0}+4.9763 \cdot 10^{4}$

This function is integrated to compute the cumulated outflow, $V_{\text {out }}$, as a function of $z_{0}$ : 
$V_{\text {out }}\left(z_{0}\right)=\int_{0}^{z_{0}} A(z) d z$

At the Provo level $z_{0}=125 \mathrm{~m}$, and $V_{\text {out }}=5320 \mathrm{~km}^{3}$. The waterlevel drop, $z_{0}$, can also be expressed as a function of $V_{\text {out }}$. Although the isostatic corrections are important in the deeper areas of the lake, their effect on hypsometry between the Provo and Bonneville levels is relatively small, being under $3.9 \%$ for $A\left(z_{0}\right)$.

\subsection{OD numerical model}

To apply the OD model, we set the lake at the Bonneville level $\left(z_{0}=0\right)$ and imposed an initial outlet channel of $3 \mathrm{~m}$ depth $\left(z_{s}\right)$ and $30 \mathrm{~m}$ width $(W)$. This initial channel geometry has little effect in the peak flow and the final excavated cross-section, as described below. The Manning's coefficient is $n=0.05$, a typical value assigned for outburst floods (Garcia-Castellanos et al., 2009). A gross estimate of the erodibility coefficient can be obtained from an energy and erosion balance for the entire flood event. When a control water-volume at depth $z$ and thickness $d z$ leaves the lake and it descends to the Provo level $\left(z_{L}\right)$, the change in gravitational potential energy is (Fig. 3):

$d E_{p}=\rho g A(z) d z\left(z_{L}-z\right)$.

For a total water-level drop from $z=0$ to $z=z_{L}$, the released potential energy is obtained by integration of Eq. (12) using $A(z)$ from Eq. (10), resulting in $3.4 \cdot 10^{18}$ Joules (J), approximately corresponding to the total energy dissipated through the outlet, $W_{r}\left(z_{L}\right)$, assuming negligible kinetic energy at level $z_{L}$ of the outflow. The total eroded volume (Subsection 2.2) is $V_{E R D} \sim 1.13 \mathrm{~km}^{3}$. By definition of $f_{y}$ and $\varepsilon_{V}$ (see Subsection 2.3) $f_{y} W_{r}\left(z_{L}\right)=\varepsilon_{V} V_{E R D}\left(z_{L}\right)$, and then their ratio $f_{y} /$ $\varepsilon_{V} \sim 3.3 \cdot 10^{-10}$ (S.I. units). But this is a lower bound since the poorly consolidated alluvial cover of the former Marsh Creek fan was likely eroded early in the flood and before all the water drained out of the lake (and thus, with a lower value for the dissipated energy). Once the alluvium was removed, outflow probably continued with little further incision into the bedrock. We examine this more thoroughly with the 2D hydrodynamic model (Subsection 3.4), but here, where the aim is to examine controlling parameters, we assume $f_{y} / \varepsilon_{V}=1.4 \cdot 10^{-9}$, a value four times greater than the minimum value required by the total energy balance. For the lateral erosion (Eq. (4)) the factor $f_{L}$ has been set as 5.25 for the outlet sides. This value will be justified by the final aspect ratio $W / z_{s}$, which corresponds to the excavated channel at Red Rock Pass. Finally, the ratio $f_{y} / \varepsilon_{V}$ is reduced by a factor 100 in Eq. (3) when the incision depth reaches the inferred level of bedrock near the Provo level (defined at $z_{s}>124.5 \mathrm{~m}$ ).

These parameters and boundary conditions enable numerical solution of Eqs. (1)-(5), which define the OD model (Fig. 4). The depth of the outlet sill $\left(z_{s}\right)$ monotonically increases until reaching the inferred bedrock level, at which point vertical incision is negligible because of the smaller $f_{y} / \varepsilon_{V}$ ratio. At that time, the water-level drop in the lake $\left(z_{0}\right)$ attains an equilibrium state at the Provo level. The maximum hydraulic head, $h_{S}$, is $54.3 \mathrm{~m}$. The peak flow is $0.93 \mathrm{~Sv}$ and it is achieved for an incision depth of $117.1 \mathrm{~m}$. This is near the final incision value of $125 \mathrm{~m}$, indicating that peak discharge is primarily controlled by the lake hypsometry. The final width of the channel is $3.27 \mathrm{~km}$, consistent with the dimensions of the trench eroded into Marsh Creek fan at Red Rock Pass.

Sensitivity tests show that minor variations in the initial conditions may influence the timing of peak discharge but have little effect on peak discharges. For example, a starting scenario with an initial outlet channel $5 \mathrm{~m}$ deep and $100 \mathrm{~m}$ wide (compared with the base run of $3 \mathrm{~m}$ deep and $30 \mathrm{~m}$ wide) but with otherwise identical parameters reduces the time to peak flow by several weeks, but decreases peak discharge by only $2 \%$ (Fig. 4). By contrast, the model is more sensitive to erosion rate (Fig. ESM-1, in electronic supplementary material). Increasing the $f_{y} / \varepsilon_{V}$ ratio by a factor two leads to a peak flow of $2.1 \mathrm{~Sv}$ at $\mathrm{t}=0.237 \mathrm{y}$, when $z_{s}$ reaches the bedrock level, at which point erosion slows markedly. Decreasing the $f_{y} / \varepsilon_{V}$ ratio by a factor 2 reduces the peak flow to $0.28 \mathrm{SV}$ at $\mathrm{t}=0.927 \mathrm{y}$ and $z_{s}=72.4 \mathrm{~m}$. In this situation, the peak discharge occurs prior to incision reaching the bedrock threshold because of the significant lake drainage (and diminished head) during the slow opening of the outlet. Thus, the OD model clarifies the role of some of these controlling factors and shows that the timing and magnitude of the peak Lake Bonneville outflow discharge could have been governed by either (or both) hypsometry and the depth-variability of the erodibility coefficient at the outlet, depending on the values of these parameters. Although these OD approximations help outline controlling factors, their application is limited because they rely on untested assumptions and simplifications, and do not account for the 2D and 3D effects of topography and hydrodynamics (Abril and Periáñez, 2016).

\section{3. $2 D$ simulations of the internal dynamics of the Bonneville Lake during the flood}

Our 2D modeling efforts evaluate the effects of outlet evolution and internal lake hydrodynamics on controlling the outflow hydrograph at Red Rock Pass. These results can be compared to the previous paleohydraulic estimates of discharge made downstream along the Bonneville Flood route.

We first assess the role of internal lake hydrodynamics. During the flood, outflow at Red Rock Pass derives from lake water moving toward the outlet. This movement is forced by spatial gradients in its free surface. A question addressed by the modeling is how these gradients, and as a consequence, lake outflow at Red Rock Pass, may be inhibited by constrictions within the lake basin. One prominent constriction is Bear River canyon, a narrow waterway connecting the main body of the Bonneville Lake to the Cache Valley which in turn leads to the outlet area at Red Rock Pass.

We approach this question by use of a preliminary 2D model of the entire Lake Bonneville at a spatial resolution of 30 arc-seconds. This model is based on the modern terrain elevations and instantaneous erosion of the outlet from the Bonneville level to Provo level. This simplified application shows gravity waves propagating away from the outlet and through the lake basin for a short transient period, but flow soon approaches a quasi-steady-state regime. This steady regime produces smooth surface water spatial gradients for the whole lake basin except for the area of Bear River canyon, indicating that this internal constriction regulates flow moving through Lake Bonneville and toward the outlet.

From these preliminary results, it is evident that the 30-arc-second model is too coarse to fully evaluate the hydrodynamic control at Bear River canyon and that at of second narrow passage $5 \mathrm{~km}$ south of Bear River canyon. This pass, at the head of Willow Creek near Beaverdam, is wider and shallower than Bear River Canyon but also connects the Great Salt Lake basin with Cache Valley at high lake levels. The 30-arcsecond model is also too coarse to evaluate conditions at the narrow Red Rock Pass outlet. To better evaluate these fine-scale features on the flow dynamics within the lake, we created a finer model with a spatial resolution of 4 arc-seconds, but, for computational efficiency its domain is limited to the northeastern area of the lake. This 4-arc-second model domain includes Bear Creek canyon, Beaverdam pass, and the Red Rock Pass outlet (Fig. 5). The associated terrain model incorporates the isostatic correction and the reconstructed post-flood (Provo level) outlet conditions (see Subsection 2.2).

The uniform water elevations predicted in the E-W direction by the 30 -arc-second model in northern Great Salt Lake area allow us to specify a Dirichlet-type boundary condition for the 4-arc-second model one, consisting of a uniform value, $z_{0}$, for the water level along its southern open boundary. The 4-arc-second model is then initialized from conditions of static water and an instantaneous dam failure, and run until reaching quasi steady-state outflow at Red Rock Pass.

An example of 4-arc-second model output is shown in Fig. 5, which corresponds to a water level at the southern boundary of $z_{0}=14 \mathrm{~m}$ below the Bonneville level. For this situation, the water flow through 


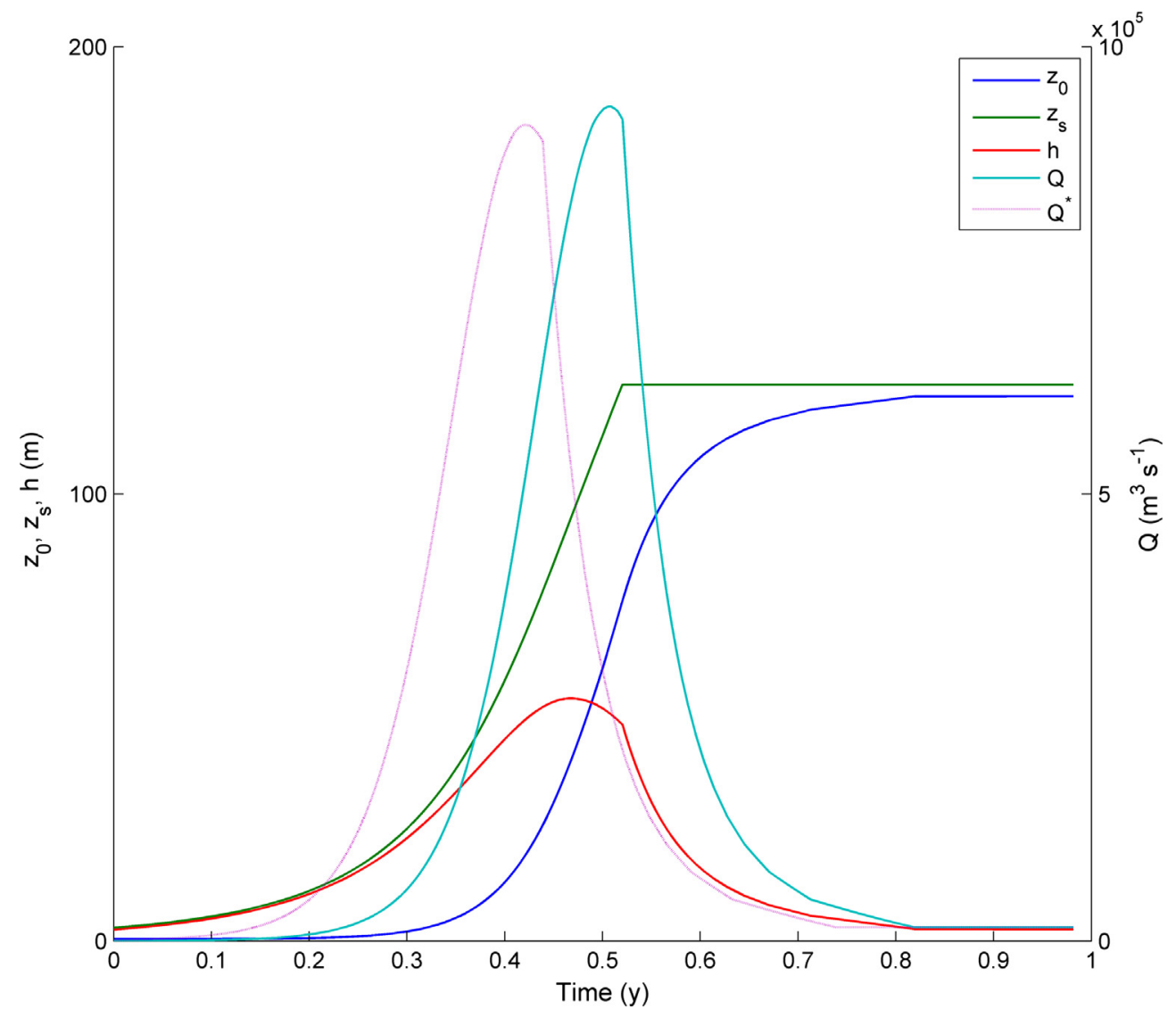

Fig. 4. Computed time series of the lake level, $z_{0}$, the depth of the sill, $z_{s}$, the hydraulic head, $h$, and the water flow, $Q$, after solving Eqs. (1)-(5) (OD model) with initial conditions $z_{O}=0, z_{s}=3$ and $W=30$ with $n=0.05, f_{y} / \varepsilon_{V}=1.4 \cdot 10^{-9}$ and $f_{L}=5.25$ at each flank (all the units are given in I.S.). The curve $Q^{*}$ is the solution for the same model conditions but with a larger initial trench of $z_{s}=5$ and $W=100 \mathrm{~m}$
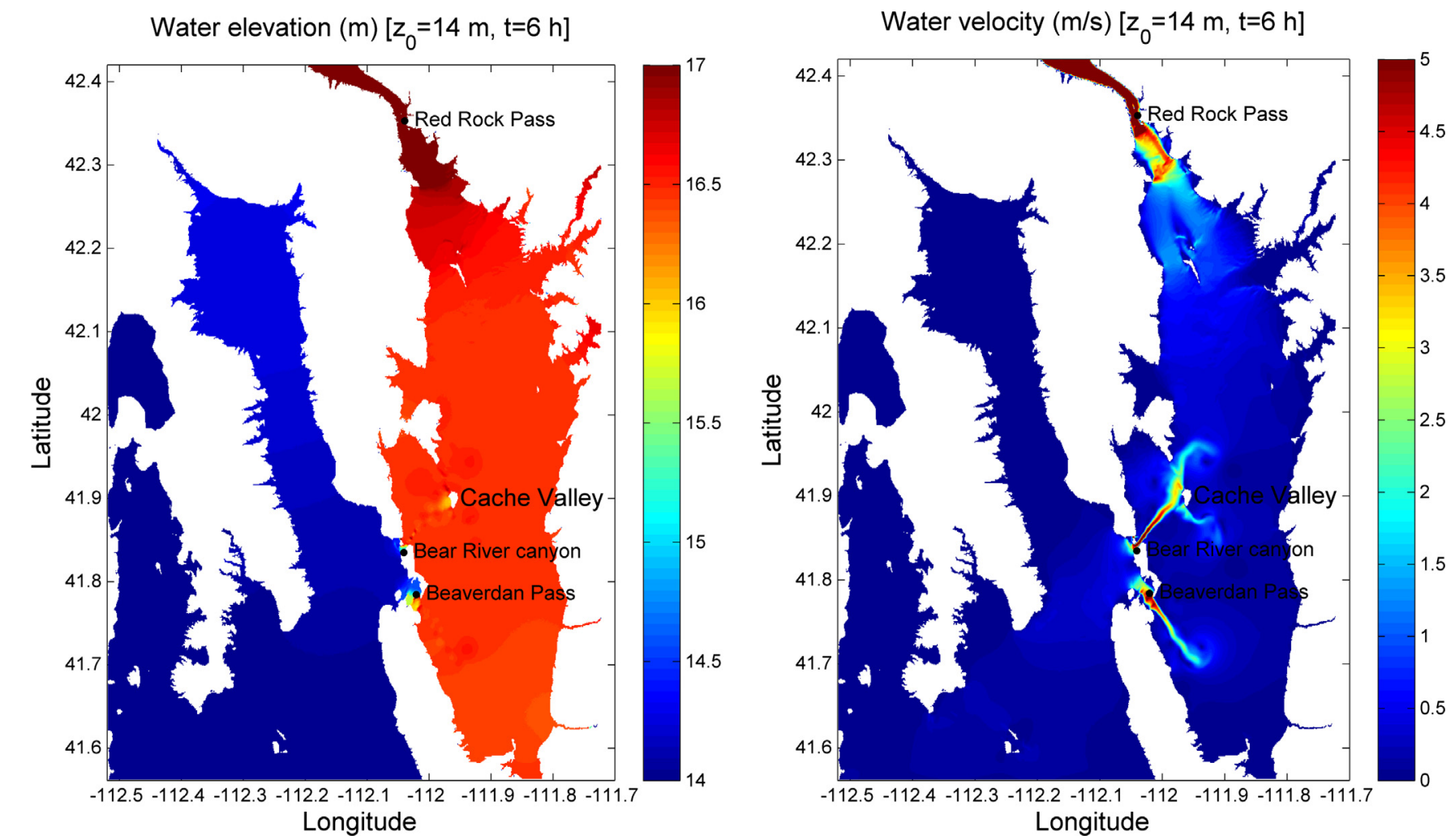

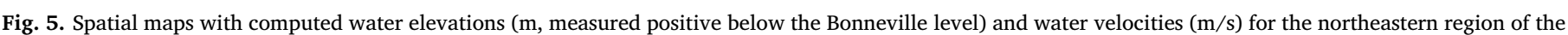

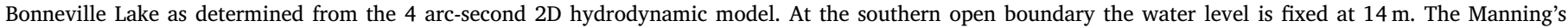

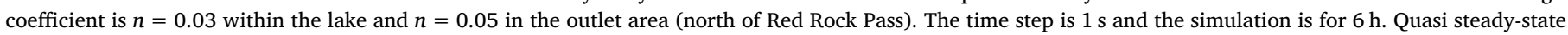

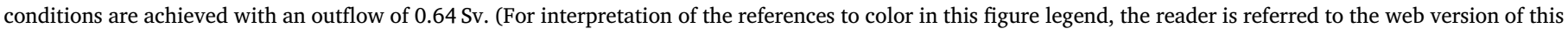
article.) 

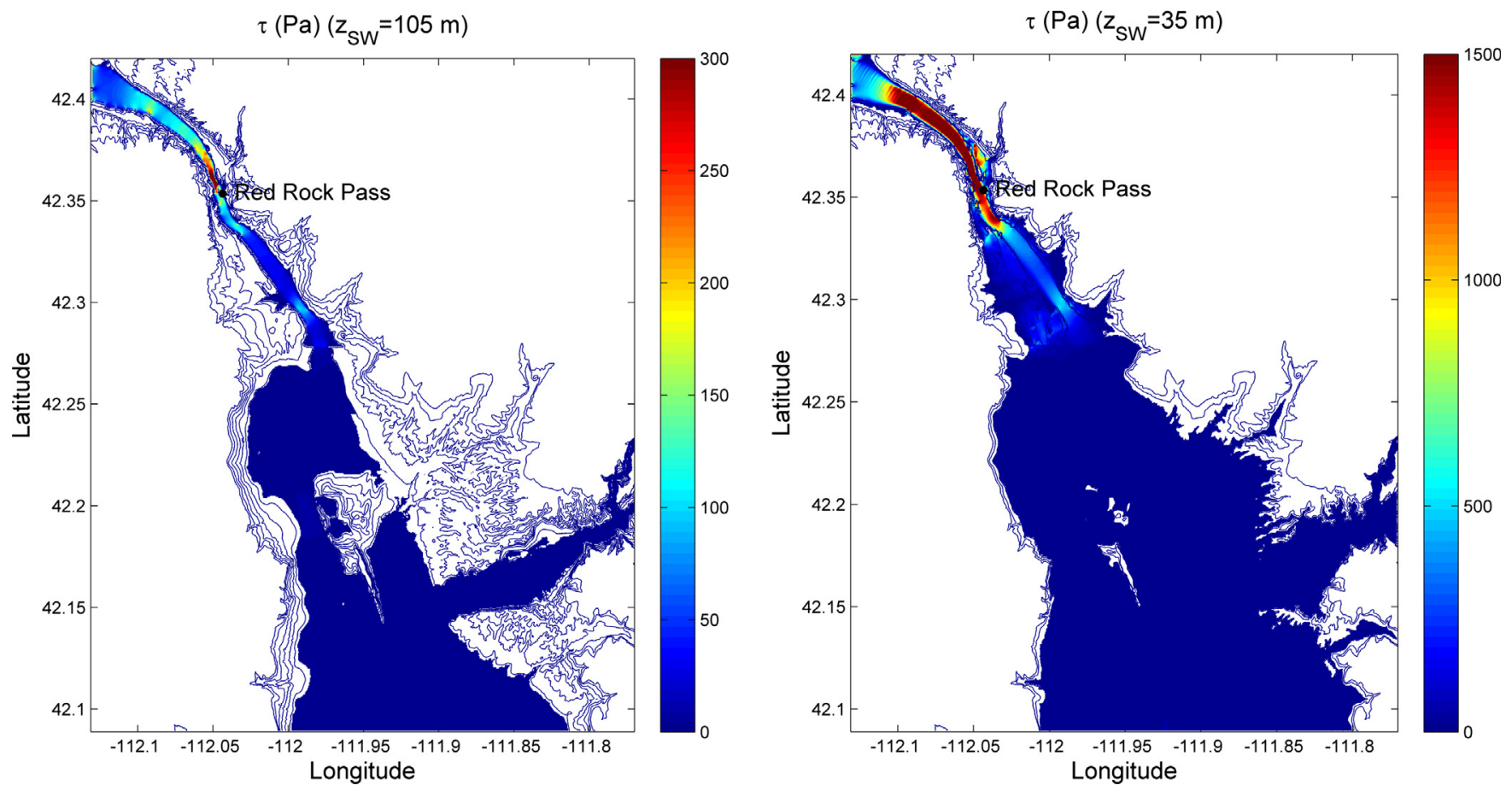

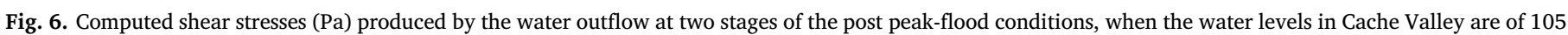
and $35 \mathrm{~m}$ below the Bonneville Level, respectively. Terrain elevation contour-levels are plotted at the Bonneville level and at $20 \mathrm{~m}$ intervals below it.

Red Rock Pass is steady-state at $0.64 \mathrm{~Sv}$ and equilibrated with the combined inflow into Cache Valley through the Bear River canyon and Beaverdam constrictions. From the southern open boundary to the west entrances to the Bear River canyon and Beaverdam passages, the waterlevel drop is only $14 \mathrm{~cm}$. Through the passages funneling water into Cache Valley, however, the water-level drop is $2.3 \mathrm{~m}$ and flow velocity locally exceeds $5 \mathrm{~m} \mathrm{~s}^{-1}$ (Fig. 5, second panel). Within Cache Valley, the water-surface gradient to the south end of the Red Rock Pass is small, only about $15 \mathrm{~cm}$, before flow accelerates through the outlet, locally exceeding $12 \mathrm{~m} \mathrm{~s}^{-1}$. The Froude number remains under 0.1 within the lake water body and below 0.5 at the outlet; thus the flow conditions are clearly subcritical.

At the initial stages of the flood, when the Red Rock Pass outlet is only partly eroded, the water flow has not reached yet its peak value and the water-level drop in the lake is likely of the order of a few meters. At this stage the Beaverdam passage together with Bear River canyon convey sufficient flow into Cache Valley without requiring large hydraulic gradients. At the final stages of the flood, the water level of the lake approaches the Provo level and the flow at the outlet progressively attenuates. At this lower stage, only the Bear River canyon passage conveys into Cache Valley, but because of the diminished total outflow through Red Rock Pass, only moderate hydraulic gradient is required through Bear River canyon. The situation in which these two narrow passages could have exerted a major hydraulic control is at about the time of peak flow through Red Rock Pass, which, as described in subsequent sections, is attained with the lake stage in Cache Valley is 14-15 $\mathrm{m}$ below the Bonneville level.

Water elevations in Fig. 5 (4-arc-second model) show smooth a north-south gradient within the Cache Valley. This is the case for all specified water levels at the southern open boundary, justifying the application of the same Dirichlet-type boundary condition (at their respective southern open boundaries) for the higher-resolution models of 2 and 1 arc-seconds (see computational domains in Fig. 1). These models aim to provide more accurate estimations of the water outflow at Red Rock Pass during the Bonneville Flood as a function of water level south of Swan Lake, in Cache Valley (labelled $z_{S W}$ hereafter) and quantifying erosional processes. Note that $z_{S W}$ is associated with the general hypsometry of the main body of the lake, $z_{0}$, by means of a correction factor accounting for the water-level drop through Bear River canyon and the Beaverdam passage, as described in more detail in Subsection 3.4.

\section{4. $2 D$ simulations of the hydrodynamics and erosion at the outlet area during the Bonneville Flood}

In this final modeling scenario, we focus on the eroding outlet at Red Rock Pass and its control on the peak flow and duration of the Bonneville Flood. This is a strongly coupled process involving the overflow through the outlet, erosion of the outlet, and draining and lowering of Lake Bonneville. Plausible solutions are independently constrained by knowledge of the peak discharge determined from downstream flood evidence.

We first assess outflow discharge as a function of lake level $z_{S W}$ for the reconstructed outlet geometry at the final Provo level. This, along with the downstream features which constrain the value of the peak flow, allows estimating the water level at peak flow conditions. A sequential energy balance can be then applied for computing the outflow during the erosive phase, which also requires solving the relationship between water levels in Cache Valley and the main Great Salt Lake basin, $z_{S W}$ and $z_{0}$.

\subsubsection{Post-peak flow through Red Rock Pass}

We separate the rising limb of the outflow hydrograph at Red Rock Pass from the waning limb in order to more realistically parameterize erosion at the outlet. From our 0D model, we infer that peak flow conditions are attained when the relatively erodible alluvium of the Marsh Creek fan has been removed and the outlet level has reached the underlying bedrock. At this point, the low erodibility of the bedrock implies negligible vertical incision. Thus, a key simplification is that we assume that most of the significant outlet erosion occurs prior to peak flow, during the rising hydrograph. Subsequent to the peak, outflow is then essentially controlled by the water level in Cache Valley, which progressively decreases until reaching the bedrock level at the sill, enabling the lake to equilibrate at the Provo level. 


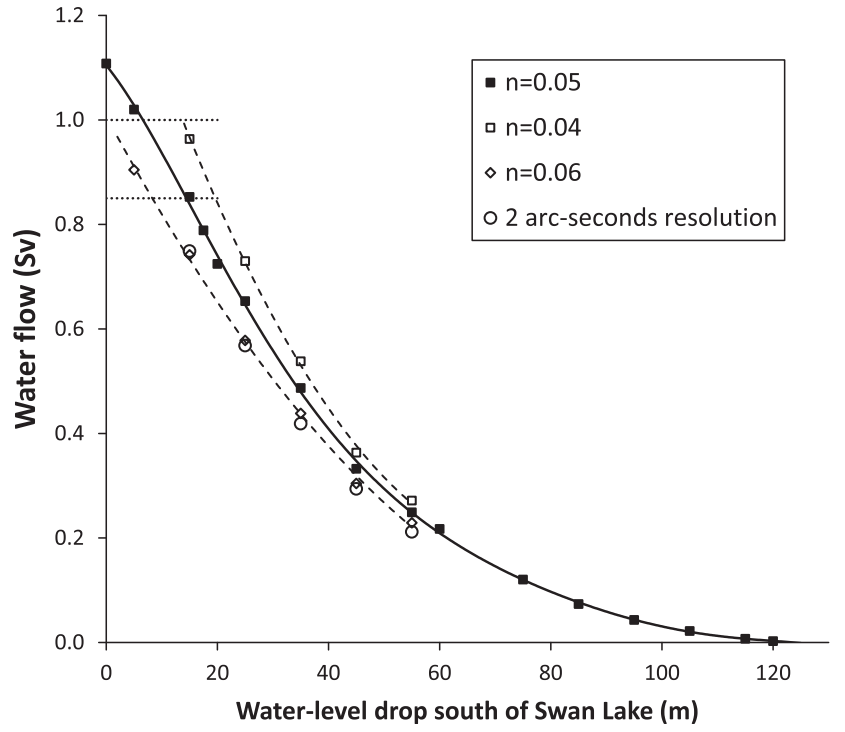

Fig. 7. Computed (from 2D model with 1 arc-second resolution) quasi steadystate water outflows as a function of the water-level drop in Cache Valley for the post peak-flow stage (using the terrain elevations of Fig. 2, panel 2). Also shown is model sensitivity to spatial resolution and Manning's coefficient. Horizontal dashed lines depict the peak discharge range as estimated from downstream flood evidence.

For this framework, we determine the post-peak outlet flow conditions by modeling flow through a stable outlet at Red Rock Pass, as reconstructed for the Provo level (Fig. 2), as a function of the water level south of the Swan Lake area, $z_{S w}$. We applied the 2D hydrodynamic model with 1 arc-second resolution to a domain which contains the outlet area, and where constant values of $z_{S W}$ are specified at the southern open boundary (Fig. 6). The reference frictional setup is used as a base. The model is initiated by instantaneous dam failure at Red Rock Pass, and quasi steady-state flow through the outlet is typically attained after $2-4 \mathrm{~h}$ of simulation time. The time step varies with the flow conditions, generally between 0.1 and $1.0 \mathrm{~s}$. An example of time series of outflow can be seen in Fig. ESM-2.

This scenario was modeled for several specified values of $z_{S W}$ and for several trials investigating sensitivity of the model to model and flow parameters (Figs. 6 and 7). For the reference model, the peak outflow ranges up to $1.11 \mathrm{~Sv}$ for the implausible end-member conditions of a fully eroded outlet but the lake still at the $1552 \mathrm{~m}$ Bonneville level, to about $0.003 \mathrm{~Sv}$ at $5 \mathrm{~m}$ above the Provo level.

Sensitivity tests applied to this reference model show the effects of key uncertainties (Fig. 7): i) Spatial resolution: Decreasing model resolution has a significant effect. For an application of the reference model for $z_{S W}$ of the range $15-55 \mathrm{~m}$ with a spatial resolution of 2 arcseconds (instead of 1 arc-second), the resulting outflows were about $15 \%$ lower, indicating the importance of an accurate description of the topography of the relatively narrow passage at the outlet. ii) Manning coefficient: Increasing Manning's $n$ to 0.06 from the reference value of 0.05 decreases the outflow discharge by about $10 \%$. Similarly, decreasing $n$ to 0.04 increases flow by $11 \%$. Decreasing Manning's $n$ within the lake from 0.03 to 0.02 amplifies internal oscillations during the transient phase and increases outflow at Red Rock Pass by 1.0\%. iii) Eddy viscosity: Reducing the nominal value of $\mathrm{A}=10 \mathrm{~m}^{2} \mathrm{~s}^{-1}$ by a factor 10 produces numerical fluctuations as great as $3 \%$ about the mean value of the outflow, which varies less than $1.7 \%$ (Fig. ESM-2). Increasing $A$ by a factor 10 reduces outflow by $15 \%$, as shown in Fig. ESM-2. Together, these results show that the most influential hydraulic parameter is Manning's $n$, for which a reasonable range affects the computed flow through Red Rock Pass by a factor of about $10 \%$.

Additionally, for very shallow flow over the outlet, as the falling
Lake Bonneville stage approaches the Provo level near the end of the flood, model results are sensitive to details of topographic reconstruction. But when lake levels are still high earlier in the waning phase of the flood, it is the overall outlet geometry that is most influential. Because erosion is neglected in these model runs, the resulting flows estimated for the outlet represent upper bounds on the actual outlet flow.

As described earlier, hydraulic modeling in conjunction with downstream evidence of the Bonneville Flood indicates a peak discharge near the Red Rock Pass outlet of 0.85-1.0 Sv (O'Connor, 1993). For the reference model, a downstream peak discharge estimate of $0.85 \mathrm{~Sv}$ implies a water-level drop $\left(z_{S W}\right)$ of $15 \mathrm{~m}$ through the fully eroded outlet (Fig. 7). Considering the uncertainty of the downstream estimate, the permissible range for $z_{S W}$ is 7 to $15 \mathrm{~m}$. Additionally considering Manning's $n$ values of 0.04 to 0.06 , their respective permissible ranges for $z_{S W}$ are 14 to $20 \mathrm{~m}$ and $\sim 3$ to $8 \mathrm{~m}$ (note that $z_{S W}$ cannot be zero at peak flow because of the water-level drop through Bear River canyon and Beaverdam). The water-level drop in the main waterbody, $z_{0}$, at which the peak flow is attained, must also be consistent with the range of acceptable values for the erodibility of the alluvium cover. That is, a very small water-level drop at the peak flow would imply the removal of $1.13 \mathrm{~km}^{3}$ of material with the expenditure of a very small amount of energy, requiring an unrealistically high erodibility coefficient. At this point, the relationship between $z_{S W}$ and $z_{0}$ must be quantified to proceed on with the analysis

\subsubsection{Accounting for the Bear River canyon and Beaverdam passage constrictions}

The numerical experiment of Subsection 3.4.1 has been repeated with the mesh of 4 arc-seconds of resolution and the domain of Fig. 5 (see Subsection 3.3). Fig. ESM-3 plots the computed water outflow at Red Rock Pass as a function of $z_{0}$. It follows the same pattern of Fig. 7 (1 arc-second resolution model), although with slightly lower values. The maximum water flow at $z_{0}=0$ is $0.963 \mathrm{~Sv}$, a $13 \%$ lower than the one computed for $z_{S W}=0$ (Fig. 7). This is due to both the coarser resolution (see sensitivity tests in Fig. 7) and the hydraulic gradients at Bear River canyon and the Beaverdam passage. Model outputs also provide estimates of the differences in water levels between the main body of the Bonneville, $z_{0}$, and the Swan Lake area in Cache Valley, $z_{S W}$ (Fig. 8).

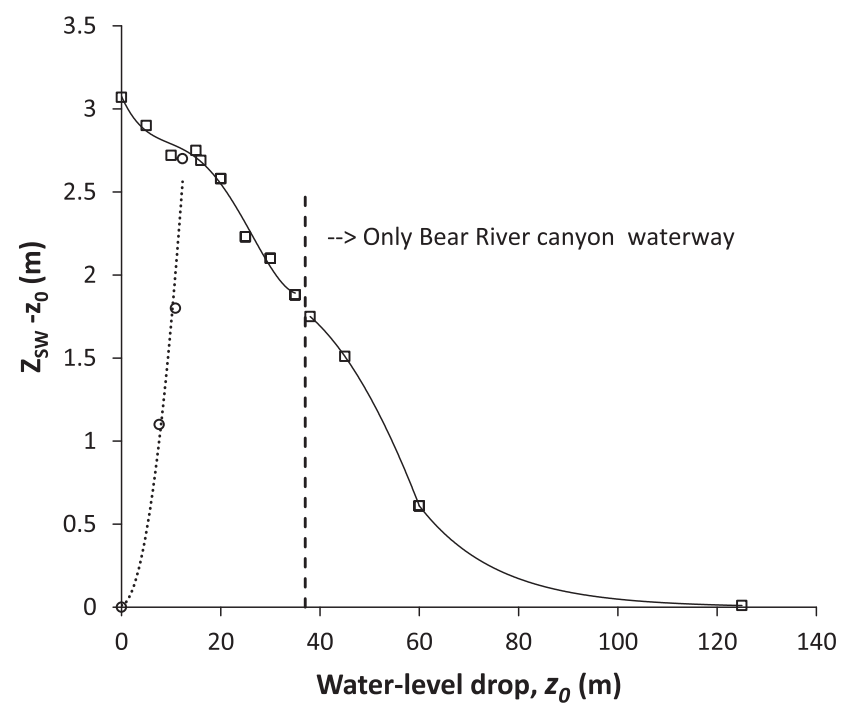

Fig. 8. Computed differences in water levels (open squares, 2D model, 4 arcseconds resolution and computational domain in Fig. 5) between the main body of the Bonneville Lake and Cache Valley as a function of the lake-level drop from the Bonneville level $\left(z_{0}\right)$ during the flood. The dashed-line and open circles are a tentative extension of these results for the pre peak-flow stage (see text for details). 
For conditions of peak outflow of $0.85 \mathrm{~Sv}$ through a fully eroded Red Rock Pass, the associated $z_{S W}$ is $\sim 15 \mathrm{~m}$ (Fig. 7). At such a lake level, the constricted passages through Bear River canyon and the Beaverdam passage resulted in the main body of the lake being about $2.7 \mathrm{~m}$ higher than $z_{S W}$ in Cache Valley. If these hydraulic constraints were absent and $z_{S W}=z_{0}=12.3 \mathrm{~m}$ (instead of $15 \mathrm{~m}$ ), the relationship of Fig. 7 gives an estimate for outflow $Q=0.90 \mathrm{~Sv}$ compared to $\mathrm{Q}=0.85 \mathrm{~Sv}$ for $z_{S W}=15 \mathrm{~m}$. This difference indicates that the hydraulic restrictions between the main lake area and Cache Valley may have decreased the peak water flow as much as $6 \%$. A similar computation for peak flow conditions of $1.0 \mathrm{~Sv}$ (in Fig. 7) leads to a correction of 4\%. Both estimates are for conditions of $n=0.05$.

\subsubsection{Accounting for erosion of the outlet}

Erosion of the outlet, for which the 0D model results indicate was mainly during the period of increasing flow at Red Rock Pass, can be parameterized in combination with the results obtained so far. Combining curves from Figs. 7 and 8, the peak flow conditions of $0.85 \mathrm{~Sv}$ (with $n=0.05$ ) is attained at a water level for Lake Bonneville of $z_{0}=12.3 \mathrm{~m}$, with a total energy dissipation of $7.0 \cdot 10^{17} \mathrm{~J}$, as determined by integrating Eq. (3) and accounting for the $0.5 \%$ correction due to the lower water level in the Cache-Swan Lake. Thus, the removal of $1.13 \mathrm{~km}^{3}$ of alluvium, as estimated from the reconstructed outlet topography associated with the Bonneville and Provo levels, leads to a $f_{y} / \varepsilon_{V}$ ratio of $1.6 \cdot 10^{-9}$ (S.I. units). This value is larger by 2 orders of magnitude than that obtained by Abril and Periáñez (2016) and GarciaCastellanos et al. (2009) for the former Strait of Gibraltar during the Zanclean flood of the Mediterranean, a result consistent with the more erodible alluvial fan deposits of the blocking Marsh Creek fan compared to consolidated Oligocene flysch deposits underlying the Strait of Gibraltar. The $f_{y} / \varepsilon_{V}$ ratio is the main factor for the erodibility coefficient, $k_{b}$, which also depends on the hydraulic conditions (Eq. (3)). With $n=0.05$ and a mean reference depth of $65 \mathrm{~m}$ (roughly half the final incision depth), $k_{b}=1.6 \cdot 10^{-10}$ (S.I. units) or $0.0051 \mathrm{~m} \mathrm{y}^{-1} \mathrm{~Pa}^{-1.5}$.

The above analysis has been repeated for all the acceptable values of water outflow and for the three Manning's coefficients used in Fig. 7. Results are shown in Fig. ESM-4, where computed erodibilities are compared against the intervals of reference values for consolidated and unconsolidated alluvium. A Manning's coefficient $n=0.06$ produces acceptable outflows for conditions of high erodibility, those typical of unconsolidated alluvium. A Manning's coefficient $n=0.04$ produces acceptable outflows for $z_{S W}$ in the range 14 to $20 \mathrm{~m}$, requiring erodibility values typically associated with consolidated alluvium. Slightly higher values of erodibility - at the approximate transition between consolidated and unconsolidated alluvium-are predicted for $n=0.05$ for the 0.85-1.0 Sv range of known peak discharge. We infer that the erodibility scenario associated with $n=0.05$ (see references in Section 2.4) and producing an outflow of $0.85 \mathrm{~Sv}$ provides a reasonable basis for our more detailed assessment of outlet erosion through the alluvium underlying Marsh Cree fan (Section 3.4.4).

According to the 0D model, the erodibility of the Marsh Creek fan alluvium is about two orders of magnitude higher than that of the underlying bedrock. Thus, we assume that for the bedrock underlying the alluvium of Marsh Creek fan, $f_{y} / \varepsilon_{V} \leq 1.6 \cdot 10^{-11}$ (S.I. units), somewhat less erodible than the $2.1 \cdot 10^{-11}$ (S.I units) estimated by Abril and Periáñez (2016) for the former Gibraltar Isthmus, which was eroded during the Zanclean flood (their 2D-E4-3 numerical experiment).

\subsubsection{Initial conditions and early overflow}

Adopting these erodibility values, we can model the early part of the flood, as the outlet overtopped and began eroding and flow through Red Rock Pass increased. We necessarily treat this in a fairly simplistic manner because of the uncertainties in the precise nature of the outlet and initial overflow.

We start with the numerically reconstructed terrain elevations at the Bonneville level (Fig. 2, panel 3). To start overflow, we lower terrain

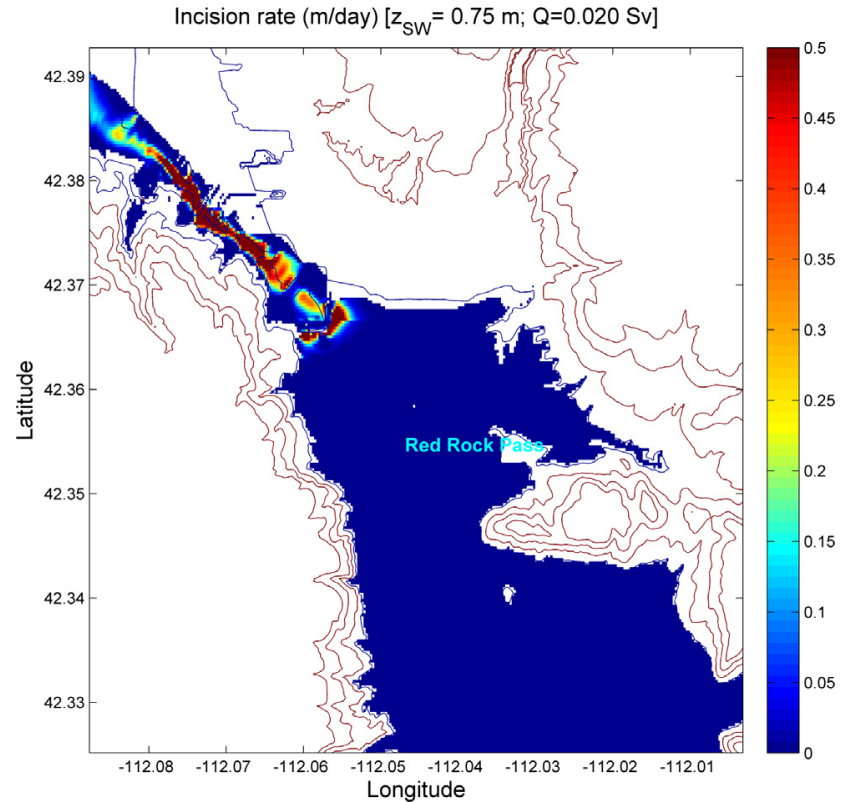

Fig. 9. Computed incision rates produced by water outflow during an early stage of the Bonneville Flood (from the 2D model with 1 arc-second resolution and $f_{y} / \varepsilon_{V}=1.6 \cdot 10^{-9}$ in S.I. units). Water flow began within a specified initial trench in the low point A' (Fig. 2). The elevation contour-levels are plotted at $10 \mathrm{~m}$ interval as in Fig. 2.

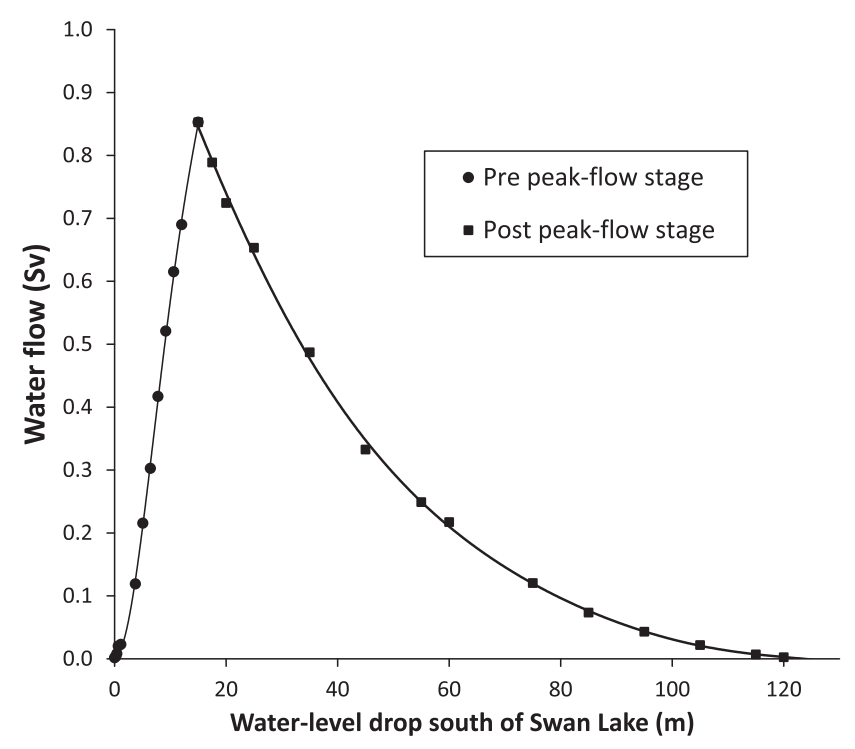

Fig. 10. Computed (from $2 \mathrm{D}$ model with 1 arc-second resolution) quasi steadystate water outflows as a function of the water-level drop in Cache Valley for the pre peak-flow stage by applying a sequential energy balance, coupling the water level with the accumulated eroded volume, and by using a crude approach of interpolated topography at the outlet. Also shown results for the post peak-flow stage (from Fig. 7).

elevations by $4 \mathrm{~m}$ in the vicinity of the low point at the divide, near point $\mathrm{A}^{\prime}$ of Fig. 2. Approximate steady state is attained in about $2 \mathrm{~h}$, at which time outflow is $1643 \mathrm{~m}^{3} \mathrm{~s}^{-1}$. This discharge is controlled by head losses along the outlet channel, which follows the western margin of Marsh Creek fan. Incision of the outlet is estimated from the computed shear stresses by using Eq. (3) with $f_{y} / \varepsilon_{V}=1 \cdot 6 \cdot 10^{-9}$ (S.I. units), as determined in Section 3.4.3. We applied the time-jump technique of Abril and Periáñez (2016) to update terrain elevations affected by erosion for intervals ranging between 20 and 40 days. Additionally, lake level was updated using the hypsometric curve (Eq. (10)), neglecting at 

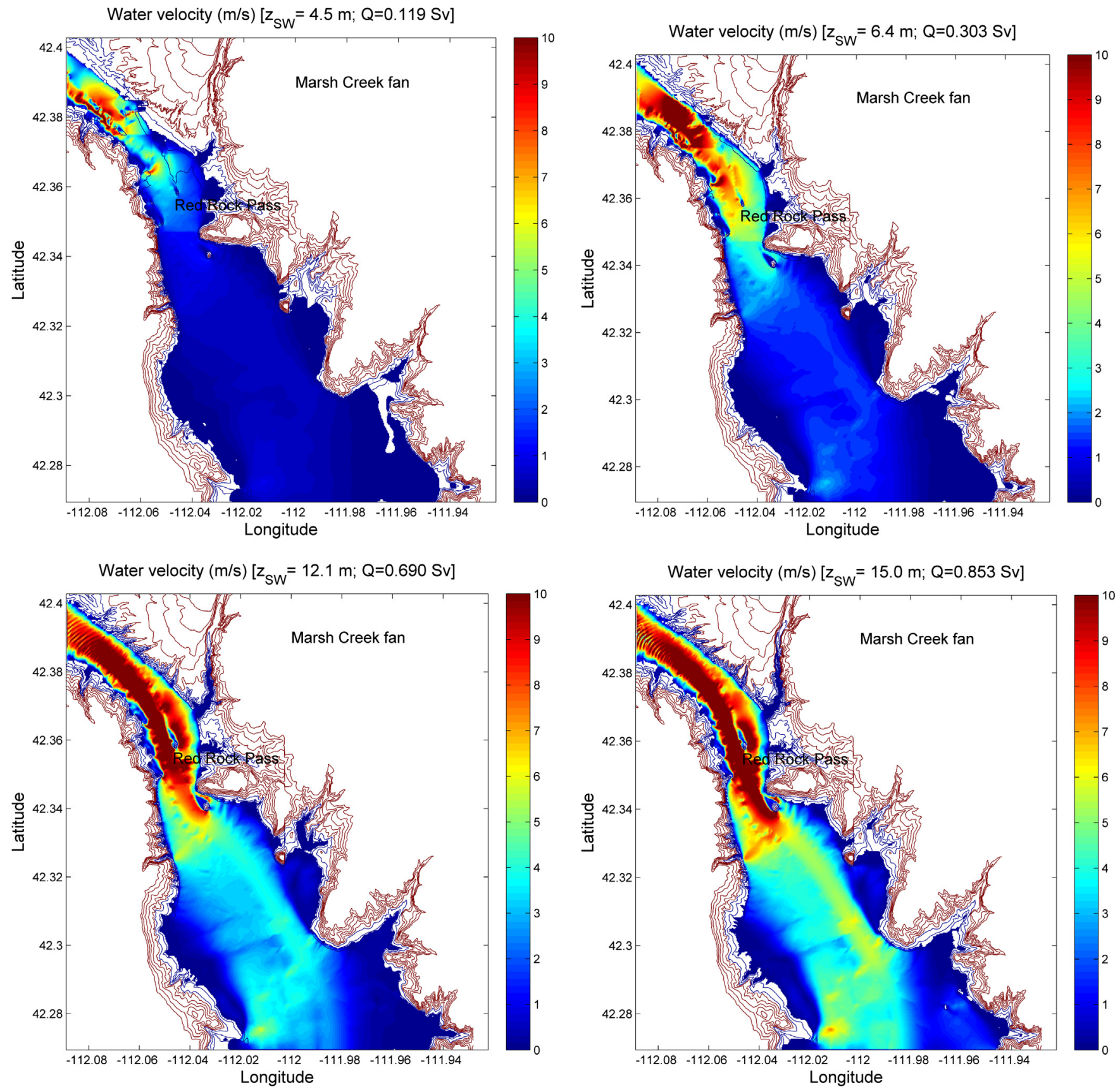

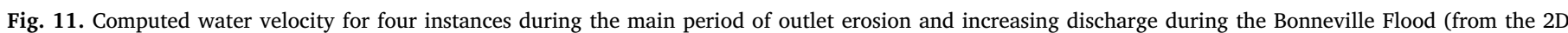
model with 1 arc-second resolution and $f_{y} / \varepsilon_{V}=1.6 \cdot 10^{-9}$ in I.S. units). The elevation contour-levels are plotted at $10 \mathrm{~m}$ interval.

this stage any correction for hydraulic gradients at Bear River canyon. This approach enabled a coupled progression of modeled initial outflow through Red Rock Pass, erosion of the outlet, and lake level lowering. The calculated situation at 4 months was an outflow of $20,180 \mathrm{~m}^{3} \mathrm{~s}^{-1}$, a lake level $\left(z_{S W}\right)$ drop of $0.75 \mathrm{~m}$, and a computed vertical erosion rate of about $0.5 \mathrm{~m} /$ day in the central channel, which is eroding retrogressively from the northeastern (downstream) margin of Marsh Creek fan (Fig. 9).

\subsubsection{The stage of massive erosion during the Bonneville Flood}

Although the actual time required to get to this very early stage $\left(z_{S W}=0.75 \mathrm{~m}\right)$ depends on many unknown factors and initial conditions, the resulting channel (Fig. 9) is a plausible starting condition for considering the main phase of erosion. This phase of the erosion was undoubtedly complex, involving knickpoint retreat as well as small and large slope failures from the eroding valley margins (Shroder et al., 2016). We grossly simplify the situation by defining sequential stages of erosion evolving from the proto-channel determined from the early overflow modeling (Fig. 9) to the final terrain elevations estimated for the final Provo level (Fig. 2, panel 2). Each sequential step of outlet topography is estimated by subtracting a constant proportion of the total vertical erosion at each grid cell, as determined by the vertical difference between the starting and final topography). For each step in channel development, the proportion subtracted increases until it reaches the value 1.0 and the final outlet topography is attained at all grid cells.

This erosion is linked to upstream water-level drop $\left(z_{0}\right)$ by applying a sequential energy balance. Thus, the energy dissipated in the outlet area for a water-level drop $z_{0}$ can be estimated by integration of Eq. (12): 


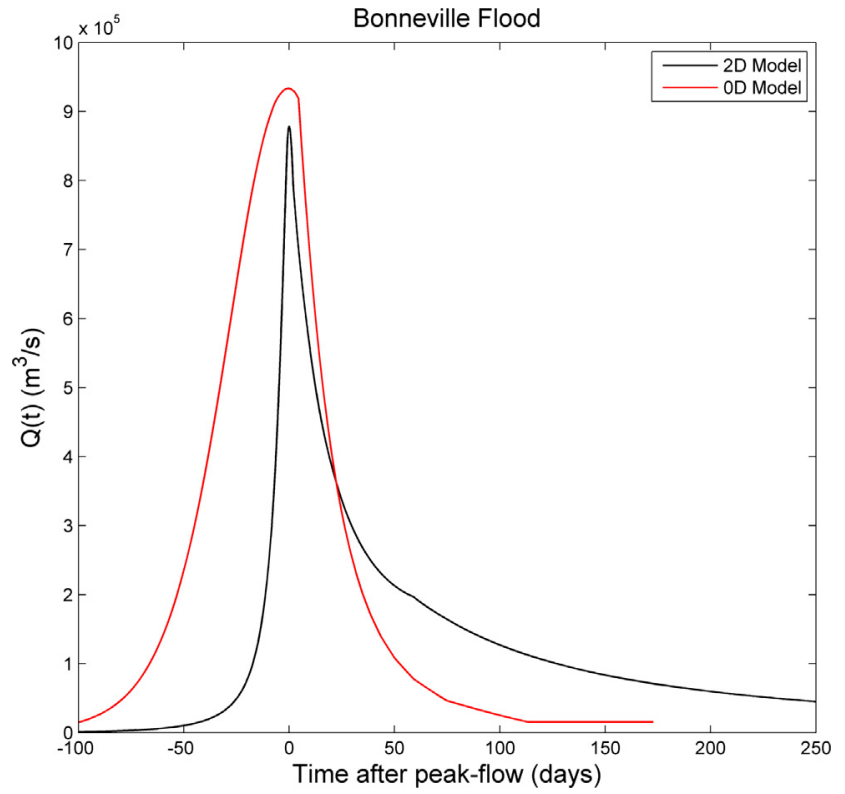

Fig. 12. Computed time series of water flow during the Bonneville Flood obtained by combining results shown in Figs. 10 and 8 with the hypsometric curve of Eq. (10). For comparison, also shown is the solution from the OD Model (Fig. 4). Time is referenced in days relative to the time of the peak flow.

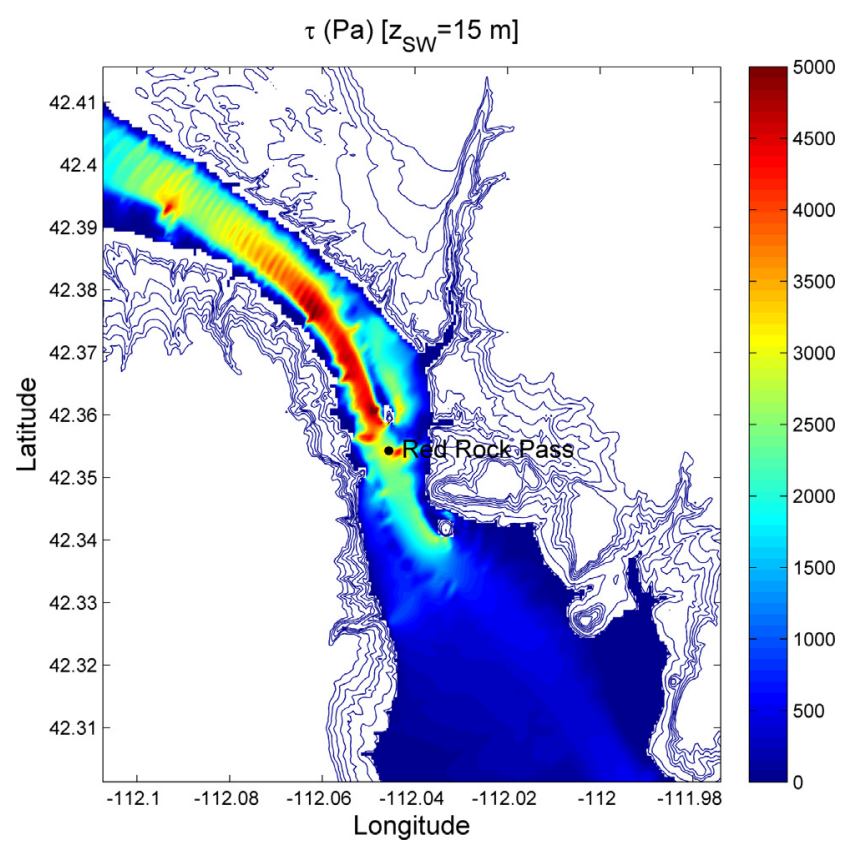

Fig. 13. Computed shear stresses $(\mathrm{Pa})$ produced by the water outflow at the outlet at peak-flood conditions, when the water level in Cache Valley is $15 \mathrm{~m}$ below the Bonneville level. Terrain elevation contours are plotted at $10 \mathrm{~m}$ intervals.

$W_{r}\left(z_{0}\right) \cong \int_{0}^{z_{0}} d E_{p}=\rho g \int_{0}^{z_{0}} A(z)\left(z_{L}-z\right) d z$

Eq. (13) has been computed for $z_{0}$ ranging from 0 to 125 at $0.5 \mathrm{~m}$ increments and then fitted by a third order polynomial with $\mathrm{R}^{2}=1.000$ (Fig. ESM-5). Thus, $W_{r}\left(z_{0}\right)$ can be specified as an analytical function of $z_{0}$. Assuming constant values for the erosion yield and the energy required to erode the unit volume, the cumulated eroded volume can be expressed as a function of $W_{r}\left(z_{0}\right)$, as well by an analytical function of $z_{0}$ :

$V_{E R D}\left(z_{0}\right)=f_{y} / \varepsilon_{V} W_{r}\left(z_{0}\right)$.
Because this high-resolution model domain depends on the Cache Valley water level $\left(z_{S W}\right)$ as a boundary condition, we need to additionally apply the relationship between $z_{S W}$ and $z_{0}$ as indicated in Fig. 8, where $z_{S W}-z_{0}$ for each $z_{0}>12.3 \mathrm{~m}$ was defined by the numerical solutions of Subsection 3.4.2. Estimating the value of $z_{S W}-z_{0}$ for the waxing portion of the hydrograph, $0<z_{0}<12.3 \mathrm{~m}$, was first based on assigning a continuous monotonic function connecting the zero level with the peak-flow value. This first estimate of $z_{0}$ (and $V_{E R D}\left(z_{0}\right)$ ) for a given $z_{S W}$, enabled a group of model runs from which quasi steady-state water flows were estimated at different stages of the erosion of the outlet. These values were then used to re-estimate new values of $z_{S W}-z_{0}$ in the range 7-12.3 $\mathrm{m}$ by applying the empirical relationship $z_{S W}-z_{0}$ vs. $Q$ that holds for the two passages between Cache Valley and the main lake basin shortly after peak-flow conditions. These results guided a refined function relating $z_{S W}-z_{0}$ to $z_{0}$ for the waxing phase of the hydrograph (Fig. 8).

We combined these relationships to produce a series of quasisteady-state model runs for estimating the rising hydrograph produced by the coupled processes of outlet erosion and lake-level lowering (Fig. 10). Incision progresses faster than the water-level drop in the lake; and thus the water flow increases leading to incision rates locally surpassing $10 \mathrm{~m} /$ day (Fig. 11 and ESM-6). The results for the maximum stage of erosion match up with the trend-line obtained in Subsection 3.4.1 for the waning flow through the fully eroded outlet at a discharge of $0.85 \mathrm{~Sv}$, which is consistent with the discharge estimates from downstream flood evidence (Fig. 10).

These results are based on the assumption of negligible incision rates after peak discharge, when the alluvium of Marsh Creek fan has been removed and the channel has reached the underlying bedrock. The most critical situation is just after the peak flow, when water flows are still over $0.7-0.8 \mathrm{~Sv}$ with extremely high bottom shear stresses. Our assumption of a $f_{y} / \varepsilon_{v}$ ratio for the bedrock being lower by a factor 100 than that for the alluvium cover would still allow incision at rates as much as $0.2 \mathrm{~m} /$ day for a water flow of $\sim 0.8 \mathrm{~Sv}$. It is possible that such incision occurred but has been covered by post-flood deposition. But it is also possible that the erodibility for the bedrock level, possibly consisting of Paleozoic landslide blocks (Shroder et al., 2016), was even lower.

\subsection{The Bonneville Flood hydrograph}

Together, the modeling results in conjunction with the hypsometry given by Eq. (10) enable reconstruction of the time series of flow through the Red Rock Pass outlet during the Bonneville Flood. We applied a piecewise polynomial fit in Fig. 10 to generate an analytical function of $Q$ vs. $z_{S W}$, and then used the function relating $z_{S W}$ to $z_{O}$ (Fig. 8) to obtain $Q$ as a function of $z_{0}$. Then we can solve Eq. (5) for time:

$d t=\frac{A\left(z_{0}\right) d z_{0}}{Q\left(z_{0}\right)}$.

Eq. (15) can be numerically integrated using the hypsometric curve from Eq. (10) (Fig. 12). Corrections in $A\left(z_{0}\right)$ by a slightly lower water level in Cache Valley have been neglected. The peak flow $(0.88 \mathrm{~Sv})$ and the duration for which the flow remains over $25 \%$ of its maximum (57.8 days) are consistent with the previous estimates by O'Connor (1990). Of the total flood volume of $5320 \mathrm{~km}^{3}, 12 \%$ exited prior to peak discharge.

This calculated hydrograph also indicates the strengths and weaknesses of the OD model (Fig. 12). The 0D model provides a similar estimate of the peak discharge, which is controlled by the overall geometry of the Red Rock Pass outlet. But the 3D character of the topography (and coupling it with energy balanced erosion) dictates a much more rapid rise in discharge than for the parameterized erosion in the $0 \mathrm{D}$ model. 


\subsection{Computed bottom shear stresses at peak flow conditions}

Model outputs allow for the computed water-current and shear stress fields at any defined stage of the flood. They are a key factor for interpreting main erosional features and entrainment of boulders by the flow. Fig. 13 shows a detailed map of the shear stress at the outlet area around the peak flow conditions. They are over $2 \mathrm{kPa}$ along the excavated channel, reaching values up to $5 \mathrm{kPa}$ at several zones downstream Red Rock Pass. The depth-averaged water currents in this area of maximum shear stress were in the range of $10-14 \mathrm{~m} / \mathrm{s}$, with stream powers of several tens of $\mathrm{kW} \cdot \mathrm{m}^{-2}$. Although the movement of boulders in stream waters is a complex process (Alexander and Cooker, 2016), the above computed velocities surpass the threshold for initializing the movement of boulders of several meters in size.

\section{Conclusions}

The Bonneville Flood was the result of pluvial Lake Bonneville rapidly lowering from the Bonneville level at $1552 \mathrm{~m}$ a.s.l. to the Provo level at $1427 \mathrm{~m}$. On the basis of 30 arc-second resolution GEBCO_08 topography, applying isostatic corrections based on Crittenden (1963), and the assigned Bonneville and Provo levels, we estimate that the total outflow during the Bonneville Flood was $5320 \mathrm{~km}^{3}$. The isostatic correction increases the total volume released by $2.6 \%$. Plausible reconstructions of the topography in outlet area before and after the flood indicate $\sim 1.13 \mathrm{~km}^{3}$ was eroded in the area of Marsh Creek fan and Red Rock Pass.

Results from a simple 0D model provide first-level understanding of the hydrograph for the Bonneville Flood, showing the control exerted by lake hypsometry and the abrupt reduction in outlet erodibility at Red Rock Pass at the Provo level. The reduced erodibility effectively halted outlet erosion, leading to diminished flow as the lake level continued to lower.

Results from 2D hydrodynamic model show that water outflow was governed by the topography of the partially incised outlet and by the local water level south of Swan Lake in Cache Valley. At about peak flow, the Bear River canyon and the Beaverdam passage forced a waterlevel difference of up to $\sim 2.7 \mathrm{~m}$ between the main body of Lake Bonneville and the Cache Valley leading to Red Rock Pass. This effect reduced peak outflow at Red Rock Pass by about $6 \%$.

A peak discharge of $0.85 \mathrm{~Sv}$, consistent with previously reported downstream erosional and depositional features (O'Connor, 1993), is predicted when the water level has dropped by $12.3 \mathrm{~m}$ in the main Bonneville Lake, involving $7.0 \cdot 10^{17} \mathrm{~J}$ of energy dissipation, a $f_{y} / \varepsilon_{V}$ ratio of $1.6 \cdot 10^{-9}$ (S.I. units), and an erodibility coefficient $k_{b} \sim 1.6 \cdot 10^{-10}$ (S.I. units) or $\sim 0.005 \mathrm{~m} \mathrm{y}^{-1} \mathrm{~Pa}^{-1.5}$. About $12 \%$ of the lake volume had evacuated at the time of peak discharge. This contrasts with the 0Dmodel, which predicts peak discharge after a drop of as much as $67 \mathrm{~m}$ (Figs. 4 and 12).

Reconstructions of the initial topography and overflow at Red Rock Pass indicate that an erosion channel at the outlet developed along the western margin of Marsh Creek fan. Locally steep gradients produce retrogressive erosion of the fan barrier and local incision rates of up to $0.5 \mathrm{~m} /$ day. From this initial condition, we model flow associated with the period of major erosion leading to the peak discharge by applying a sequential energy balance, coupling the water level with the accumulated eroded volume, and by using a crude approach of interpolated topography at the outlet. Results indicate incision rates locally surpassing $10 \mathrm{~m} /$ day.

For erosion to become negligible after reaching the bedrock at the Provo lake level, the erodibility coefficient for the bedrock must be 2-3 orders of magnitude lower than from the alluvium and weakly consolidated sediments of Marsh Creek fan.

The modeling provides a plausible reconstruction of the complete hydrograph for the Bonneville Flood. Peak flow was attained early; in 18.3 days the outflow grew from $10 \%$ up to $100 \%$ of its peak value, removing about $1 \mathrm{~km}^{3}$ of alluvium from the outlet and producing a water-level drop in the lake of $10.6 \mathrm{~m}$ in this time interval and the release of about $10 \%$ of the total outflow volume of the flood.

\section{Acknowledgements}

DGC was aided from a Spanish Government grant for this study (PR2011-0044). The manuscript benefited by reviews from Paul Jewell, Roger Denlinger, and an anonymous Journal of Hydrology reviewer.

\section{Appendix A. Supplementary data}

Supplementary data associated with this article can be found, in the online version, at http://dx.doi.org/10.1016/j.jhydrol.2018.03.065.

\section{References}

Abril, J.M., Periáñez, R., Escacena, J.L., 2013. Modeling tides and tsunami propagation in the former Gulf of Tartessos, as a tool for archaeological science. J. Archaeol. Sci. 40 (12), 4499-4508.

Abril, J.M., Periáñez, R., 2016. Revisiting the time scale and size of the Zanclean flood of the Mediterranean (5.33 Ma) from CFD simulations. Marine Geol. 382, 242-256.

Adams, K.D., Bills, B.G., 2016. Isostatic Rebound and Palinspastic Restoration of the Bonneville and Provo Shorelines in the Bonneville Basin, UT, NV, and ID. In: Oviatt, C.G., Shroder, J.F. (Eds.), Lake Bonneville: A Scientific Update. Developments in Earth Surface Processes 20, pp. 145-164.

Alexander, J., Cooker, M.J., 2016. Moving boulders in flash floods and estimating flow conditions using boulders in ancient deposits. Sedimentology. http://dx.doi.org/10. $1111 /$ sed.12274.

Alho, P., Baker, V.R., Smith, L.N., 2010. Paleohydraulic reconstruction of the largest glacial lake missoula draining(s). Quat. Sci. Rev. 29, 3067-3078.

Atwood, G., Wambeam, T.J., Anderson N.J. 2016. The Present as a Key to the Past: Paleoshoreline Correlation Insights from Great Salt Lake. In Oviatt, C.G., Shroder, J.F. (Eds.), Lake Bonneville: A Scientific Update. Developments in Earth Surface Processes 20 , pp. 1-27.

Bohorquez, P., Darby, S.E., 2008. The use of one- and two-dimensional hydraulic modelling to reconstruct a glacial outburst flood in a steep Alpine valley. J. Hydrol. 361, 240-261.

Bohorquez, P., Carling, P.A., Herget, J., 2016. Dynamic simulation of catastrophic Late Pleistocene glacial-lake drainage Altai Mountains, central Asia. Int. Geol. Rev. 58 (14), 1795-1817. http://dx.doi.org/10.1080/00206814.2015.1046956.

Bohorquez, P., García-García, F., Pérez-Valera, F., Martínez-Sánchez, C., 2013. Unsteady two-dimensional paleohydraulic reconstruction of extreme floods over the last 4000 yr in Segura river, southeast Spain. J. Hydrol. 477, 229-239.

Bunya, S., Dietrich, J., Westerink, J., Ebersole, B., Smith, J., Atkinson, J., Jensen, R., Resio, D., Luettich, R., Dawson, C., et al., 2010. A high-resolution coupled riverine flow, tide, wind, wind wave, and storm surge model for southern Louisiana and Mississippi. Part I: model development and validation. Mon. Weather Rev. 138 (2), 345-377.

Carrivik, J.L., 2007. Modelling coupled hydraulics and sediment transport of a highmagnitude flood and associated landscape change. Ann. Glaciol. 45, 143-154.

Crittenden, M.D., 1963. New Data on the Isostatic Deformation of Lake Bonneville. Geological survey professional paper 454-E. US Printing Office, Washington.

Cushman-Roisin, B., Beckers, J.M., 2011. Introduction to Geophysical Fluid Dynamics. Elsevier.

Denlinger, R.P., O'Connell, D.R.H., 2009. Simulations of cataclysmic outburst floods from Pleistocene Glacial Lake Missoula. Geol. Soc. Am. Bull. 122 (5-6), 678-689.

Finnegan, N.J., Dietrich, W.E., 2011. Episodic bedrock strath terrace formation due to meander migration and cutoff. Geology 39, 143-146.

Flather, R., Hubbert, K., 1990. Tides and surge model for shallow water - Morecambe Bay revisited. In: Davies, Alan (Ed.), Modeling Marine systems. CRC, Boca Raton Florida.

Garcia-Castellanos, D., Estrada, F., Jiménez-Munt, I., Gorini, C., Fernández, M., Vergés, J., De Vicente, R., 2009. Catastrophic flood of the Mediterranean after the Messinian salinity crisis. Nature 462. http://dx.doi.org/10.138/nature08555.

Gilbert, G.K., 1875. Explorations and surveys west of the one hundredth meridian (wheeler). Geology 3.

Gilbert, G.K., 1890. Lake Bonneville. U.S. Geological Survey Monograph 1. P. 438.

Henderson, F.M., 1966. In: Open Channel Flow. Macmillan, New York, pp. 522.

Herzfeld, M., Schmidt, M., Griffies, S.M., Liang, Z., 2011. Realistic test cases for limited area ocean modelling. Ocean Model. 37, 1-34.

Huang, W., Cao, Z.X., Carling, P., Pender, G., 2014. Coupled 2D hydrodynamic and sediment transport modeling of megaflood due to glacier dam-break in Altai Mountains, Southern Siberia. J. Mt. Sci. 11 (6), 1442-1453. http://dx.doi.org/10. 1007/ s11629-014-3032-2.

Janecke, S.U., Oaks, R.Q., 2011. New insights into the outlet conditions of Late Pleistocene Lake Bonneville, southeastern Idaho USA. Geosphere 7 (6), 1369-1391.

Jarrett, R.D., Malde, H.E., 1987. Paleodischarge of the Late Pleistocene Bonneville, Flood, Snake River, Idaho, computed from new evidence. Geol. Soc. Am. Bull. 99, 127-134.

Jewell, P.W., 2016. Quantitative identification of erosional Lake Bonneville shorelines, Utah. Geomorphology 253, 135-145. 
Kampf, J., 2009. Ocean Modelling for Beginners. Springer-Verlag, Heidelberg. Kowalik, Z., Murty, T.S., 1993. Numerical Modelling of Ocean Dynamics. World Scientific, Singapore.

Malde, H.E., 1960. Evidence in the Snake River Plain, Idaho, of a catastrophic flood from Pleistocene Lake Bonneville. U.S. Geological Survey Professional Paper. In: Short papers in the geological sciences. 400-B, pp. B295-B297.

Mayo, T., Butler, T., Dawson, C., Hoteit, I., 2014. Data assimilation within the Advanced Circulation (ADCIRC) modeling framework for the estimation of Manning's friction coefficient. Ocean Modell. 76, 43-58.

Miller, D.M., Oviatt, C.G., McGeehin, J.P., 2013. Stratigraphy and chronology of Provo shoreline deposits and lake-level implications, Late Pleistocene Lake Bonneville, eastern Great Basin, USA. Boreas 42, 342-361.

Miyamoto, H., Itoh, K., Komatsu, G., Baker, V.R., Dohm, J.M., Tosaka, H., Sasaki, S. 2006. Numerical simulations of large-scale cataclysmic floodwater: a simple depthaveraged model and an illustrative application. Geomorphology 76, 179-192.

O'Connor, J.E., 1990. Hydrology, Hydraulics, and Sediment Transport of Pleistocene Lake Bonneville Flooding on the Snake River. The University of Arizona, Idaho.

O'Connor, J.E., Clague, J.J., Walder, J.S., Manville, V., Beebee, R.A., 2013. Outburst Floods. In: Shroder, J., Wohl, E.E. (Eds.), Treatise on Geomorphology 9 (Fluvial Geomorphology). Academic Press, San Diego, California, pp. 475-510.

O'Connor, J.E., 1993. Hydrology, Hydraulics, and Geomorphology of the Bonneville Flood. Special Paper. Geological Society of America, pp. 83.

O'Connor, J.E., 2016. The Bonneville Flood - A Veritable Débâcle. In: Oviatt, C.G., Shroder, J.F. (Eds.), Lake Bonneville: A Scientific Update. Developments in Earth
Surface Processes 20, pp. 88-104.

Oviatt, C.G., 2015. Chronology of Lake Bonneville, 30,000 to 10,000 yr B.P. Quat. Sci. Rev. 110, 166-171.

Oviatt C.G., Jewell, P.W., 2016. The Bonneville Shoreline: Reconsidering Gilbert's Interpretation. In Oviatt, C.G., Shroder, J.F. (Eds.), Lake Bonneville: A Scientific Update. Developments in Earth Surface Processes 20, pp. 88-104.

Oviatt, C.G., Shroder, J.F. (Eds.), 2016. Lake Bonneville: A Scientific Update. Developments in Earth Surface Processes 20, pp. 1-659. ISBN: 978-0-444-63590-7.

Periáñez, R., Abril, J.M., 2013. Modelling tsunami propagation in the Iberia-Africa plate boundary: historical events, regional exposure and the case-study of the former Gulf of Tartessos. J. Mar. Syst. 111-112, 223-234.

Periáñez, R., Abril, J.M., 2014a. Modelling tsunamis in the Eastern Mediterranean Sea. Application to the Minoan Santorini tsunami sequence as a potential scenario for the biblical Exodus. J. Mar. Syst. 139, 91-102.

Periáñez, R., Abril, J.M., 2014b. A numerical modelling study on oceanographic conditions in the former Gulf of Tartessos (SW Iberia): tides and tsunami propagation. J. Mar. Syst. 139, 68-78.

Periáñez, R., Abril, J.M., 2015. Computational fluid dynamics simulations of the Zanclean catastrophic flood of the Mediterranean (5.33 Ma). Palaeogeogr. Palaeoclimatol. Palaeoecol. 424, 49-60.

Shroder, J.F., Cornwell, K., Oviatt, C.G., Lowndes, T.C., 2016. Chapter 4. Landslides, Alluvial Fans, and Dam Failure at Red Rock Pass: The Outlet of Lake Bonneville. In: Oviatt, C.G., Shroder Jr., J.F. (Eds.), Lake Bonneville: A Scientific Update, vol. 20. Elsevier. pp. 75-87. 